\title{
Cut-Out Calligraphy from the Fifteenth and Sixteenth Centuries: Discussion of Its Origins and Significance and Observations on the Techniques and Tools Used
}

\author{
Amélie Couvrat Desvergnes ${ }^{1}$ | ORCID: 0000-0001-8371-3046 \\ Independent book and paper conservator, Utrecht, The Netherlands \\ ameliecd@gmail.com
}

\begin{abstract}
Through the study of the materiality of three works from collections in Doha, Paris and Amsterdam, this paper intends to fill a gap in the knowledge of découpage calligraphy in Iran and shed light on its production processes. First, the origins and the context of the art will be explored through ancient and modern sources, followed by an examination of the tools used and the techniques of production, and finally an insight into the purpose or la raison d'être of the découpage technique will be presented.
\end{abstract}

Keywords

découpage - cut-out calligraphy - Iran - Timurid - filigree bookbinding - Mamluk papercut Chinese papercut

The art of découpage, or cut-out calligraphy, has been little studied by scholars for various reasons, including the scarcity of historical accounts, the relatively small number of available specimens, the dispersion of extant folios through collections worldwide and the difficulties of accurately identifying and describing this original art form. It is suspected that some collections might hold découpage specimens without being aware of it since they often highly resemble white or coloured handwriting on a darker background. It is also probable that the specimens preserved today in private or public collections in countries such as Iran have not yet been discovered and published.

This paper intends to study the materiality of this art form, fill in gaps in the knowledge of découpage calligraphy in Iran and shed light on its production through the examination of three works from collections located in Doha, Paris and Amsterdam. These works bear the signatures of renowned calligraphers and cutters who were active at the end of the fifteenth and in the first half of the sixteenth centuries and who belonged to the first generation of Iranian practitioners.

The starting point of this research project was the examination of two folios from the dī $\bar{a} n$ of Sultan Husayn Bāyqaāa $(1438-1506)$ that needed preparation for the exhibition Ferozkoh: Tradition and Continuity in Afghan Art, held at the Museum of Islamic Art in Qatar (MIA) in 2013 (Michelsen and Pelletreau, 2013: 74). Both pages were in remarkable condition and, except for affixing unstable parts of some of the letters, no further 
treatment was required. However, the exceptional execution of the folios and the realisation that the letters were actually cut one by one and pasted on the support astonished both the visitors and me and propelled me to study the découpage technique of the Iranian masters further. My curiosity was also aroused when I later encountered other cut-out specimens in my work, some of which formed the basis of the body of this research. At first, I had many questions about the precise origins of this art form, and its relationship to Chinese papercut and to the leather filigree design found in bookbinding. Then, other questions emerged from my fascination with the technical prowess of these works: how and by whom were these calligraphies made? What were the mechanisms and tools used to carry out such work? Are there any physical traces that allow us to understand the technique? Does the cutting process differ from one artist to another? Are there evolutions and improvements over time or are these linked to the practice of a particular craftsman? And finally, what is the la raison dêtre and the underlying motivations for creating this art form?

The studied corpus is composed of three artworks from three different institutions for which I worked as a paper conservator. The first artwork is a group of two folios (MS.8Og.MIAQ and MS.810.MIAQ) held at the MIA. They were part of the famous and now dispersed manuscript, the dìvān of Sultan Ḥusayn Bāyqarā, made in Herat in the 149os, whose other pages are holdings of American, European and Turkish institutions. The sumptuously illuminated initial manuscript, composed entirely of letters cut out in Nasta līq script, resulted from the collaboration between the calligrapher Sultan 'Alī Mashhadī (1453-1519) and the cutter 'Abdallāh.

The second work is a loose double-sided folio held by the Rijksmuseum in Amsterdam, entitled A Man in a Red Robe Playing a Musical Instrument (RP-T-1993-462). It features a portrait of a courtier on the recto and, on the verso, the last two hemistiches of Haafez's ghazal no. 284 and the colophon, in which the names [Bābā] Jān and Dūst-Moḥammad are penned. ${ }^{2}$ The full-length portrait on the recto shows characteristic traits of the Qazvin style: an elongated and sinuous body with a bowed head, almond-shape eyes and a tiny mouth. Based on the style of the painting and the biography of the authors of the text, this page was most likely assembled later because the courtier can be attributed to the second half of the sixteenth century, whereas the calligraphy on the verso was probably produced in the first half of the sixteenth century, most likely in Herat.

The third and last work, a complete concertina album featuring the verses of the Munājātnāma, a text written by Huājah 'Abdallāh Anșāin in the eleventh century, is held at the Musée du Louvre in Paris (MAO 2286). The twelve folios encompass the verses cut out of gold paper, arranged into cloud motifs, themselves surrounded by a grid of pink lines punctuated with small blue floral patterns. The calligraphic panels are framed with a series of coloured rulings and the borders are of gold-flecked peach, indigo blue, yellow and green papers. The last folio shows the names of the calligrapher, Mir 'Alī Ḥerāvī, and the cutter, Sangī 'Alī Badahshī, also in cut-out letters. According to the biographies of both artists, the album can be dated to the 155 os and was certainly made in Bukhara.

In addition to the above folios, I also discuss other specimens which further illustrate the techniques described. The relevance of this project is enhanced not only by the remarkable craftsmanship and the outstanding technical prowess of the artworks, but also by their authorship, since it is exceptional that the names of both the calligraphers and the cutters are attested in all three artworks. Therefore, it provides us with a good opportunity to examine early developments in découpage techniques and explore the work of renowned Iranian artists from the late fifteenth to the first half of the sixteenth centuries in eastern Iran. 


\section{Presentation of the Study}

\subsection{Definition of the Term qați}

The term qat ți or qațāic, قطاعى, means literally "cutting out." Initially used to describe filigree work, it is derived from the Arabic qața'a, "to cut" (Ohta, 2012: 261). It is translated in English as découpage or découpé from the French verb découper, "to cut out." Therefore, a cut-out specimen is often named découpage or découpé calligraphy. The term découpure was also used, mostly by French scholars in the nineteenth century (Prisse d'Avennes, 1877). The search for cut-out pages in online catalogues is made difficult by the variety of appellations: papercut, cut-paper, cut-out, découpé, découpage and even lattice work.

The cut-out process can result in two types of products (Fig. 1). The positive cut-out, extracted from a matrix or a sheet of paper, needs to be pasted onto another coloured support to be revealed and to survive as a piece on its own. The negative cut-out is the matrix, most often a light-coloured paper, from which the positive cut-out is extracted. The negative cut-out can also be pasted onto another coloured support to get a contrasting effect between the applied motive and its ground. In theory, both negative and positive pieces can co-exist independently and form two distinct works.

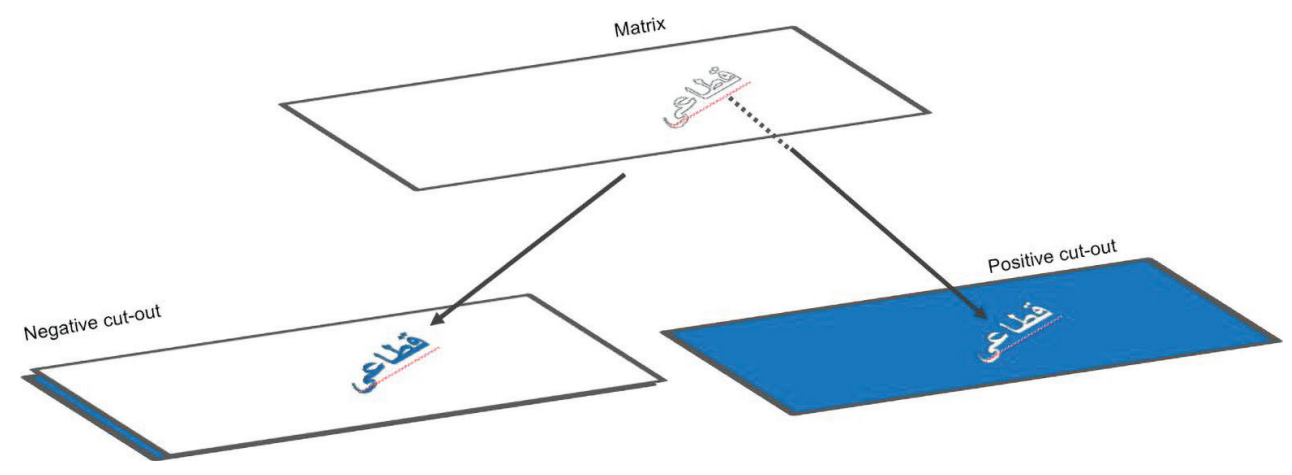

However, to the best of my knowledge, there are very few extant examples that feature an arrangement of negative and positive cutting in the same folio, or which display both the positive specimen and its negative counterpart, either associated together in the same work or conserved separately. ${ }^{3}$

\subsection{Ancient and Modern Bibliographical Sources}

A survey of written sources was conducted to collect information, not only on the artists and their historical background but also on the production process and tools used. Here is an overview of the most relevant of these. In chapter 4 of his treatise, Qādî Ḥamad lists some cutters (Minorsky, 1959: 174). ${ }^{4}$ Mușțafā 'Alī Efendī, in chapter 5 of his Menakıb-i Hünerveran, dated 1593, gives an account of masters of découpage, painters, gilders, binders, gold sprinklers, rulers and book repairers, including a brief description of the three cutters whose works are studied in this paper (Akın-Kıvanç, 2007: 261). These are also cited by C. Huart, who writes that 'Abdallāh, the cutter of the dìvann, was the son of Mir 'Alī and invented the découpage technique. He also mentions 'Abdallāh's son, Dūst-Mohammad, "whose merit is very similar to that of his father" and Sangī 'Alī Badahshī, Dūst-Mohammad's student (Huart, 1908: 325). The lineage as it is proposed by Efendī and Huart led me to enquire about the identity of the cutters, particularly that of Dūst-Mohammad, the cutter of the Rijksmuseum folio. This specific point will be
FIGURE 1

Diagram of positive and negative cut-out

(C) A. COUVRAT DESVERGNES 
discussed in the second part of the paper. The most complete essay on the art of qat $t^{c} i$ in Iran, written by Y. Zokā, contains the history, techniques, tools and biographies of cutters from the onset of the craft up to the Qajar era (Zokā, 2000). Nevertheless, the given information is not always complete and often lacks the collection's name, shelf marks and folio numbers, which make the specimens difficult to locate. Other succinct information on the production process is given by A.M. Tākestānī, based on his own artistic practice (Tākestānī, 1993). There is also an entry summarising the history and artists on the Encyclopaedia Iranica website, written by B. Schmitz. ${ }^{5}$ J.M. Rogers describes and reproduces some significant folios in Turkish and Iranian albums from Istanbul libraries (Rogers, 1999). However, most of his attributions were questioned later by F. Çağman in her extensive monograph Kat i: Cut Paper Works and Artists in the Ottoman World (Çağman, 2014). Her reference work fills the gaps in the knowledge of Turkish découpage works, delves into the first developments in the art of bookbinding and shows how the artists working under the Qaraqoyunlu rulers contributed to the dissemination of the craft. However, the sources mentioned above only briefly include technical information about the production processes and implements. Confronted with this scarcity of information and needing further technical details about tools and methods, I enlarged my research to include looking at the production of papercuts in China, where the Iranian techniques are said to be derived from.

\subsection{The Origins of the Découpage Technique}

Although the first examples of découpage calligraphy appeared in the fifteenth century in western Iran, the origin of the technique remains uncertain. Objects found previously in China, Central Asia and Egypt emphasise the production of paper or leather cut-out designs, either applied on a background or not. Further, cut-out specimens found in Turkmen manuscripts are believed to be inspired by Chinese papercuts that were brought to Iran with trade caravans in the fourteenth and fifteenth centuries, but it is not clear that there is a link. The following paragraphs aim to review, as far as possible, the production from Egypt to China and therefore to re-examine the possible origins of this art form.

Chinese papercut, called jianzhi, is an ancestral craft which is still very much alive today and lies between folk art, Buddhist and Taoist symbolic imagery and popular piety. It is performed by various social classes but remains mainly a rural tradition of streets and markets. The regional shapes and motifs are very diverse: plants and animals, landscapes, human and geometric figures, most of them bearing symbols, often intended to ensure fertility, longevity, courage or strength. Their use is manifold: from interior and exterior decorations such as paper windows, which usually stayed in place for about a year, to shorter lifespan devices such as hair or cake ornaments, paper lanterns, fans or offerings. Others have functional purposes, serving as patterns for textile embroidery or as stencils for lacquerware or pottery (Warner, 1978: 9). The earliest known papercut in the form of a rosette was found in an archaeological site dating back to the period of the Northern and Southern dynasties (AD 386-561) in the Sinkiang province. This item might have been used as a design for lacquerware or architecture (Warner, 1978: 11). Other specimens were excavated by Aurel Stein in the Dunhuang grottoes and are dated between the seventh and the tenth centuries. ${ }^{6}$ Comprising layers of paper stacked, painted and glued together and secured to a square piece of fabric with sewn loops of blue silk, the flowers embody the search for a three-dimensional effect in order to recreate architectural ornaments on the walls of tombs from of the Tang period ( $\mathrm{AD}$ 618-907). Another example (Fig. 2), from the Bibliothèque Nationale de France (BNF), recovered by Paul Pelliot in the Dunhuang grotto, appears closer to our two-dimensional cut-out calligraphies. The stupa, cut from blank paper, is in a sense 


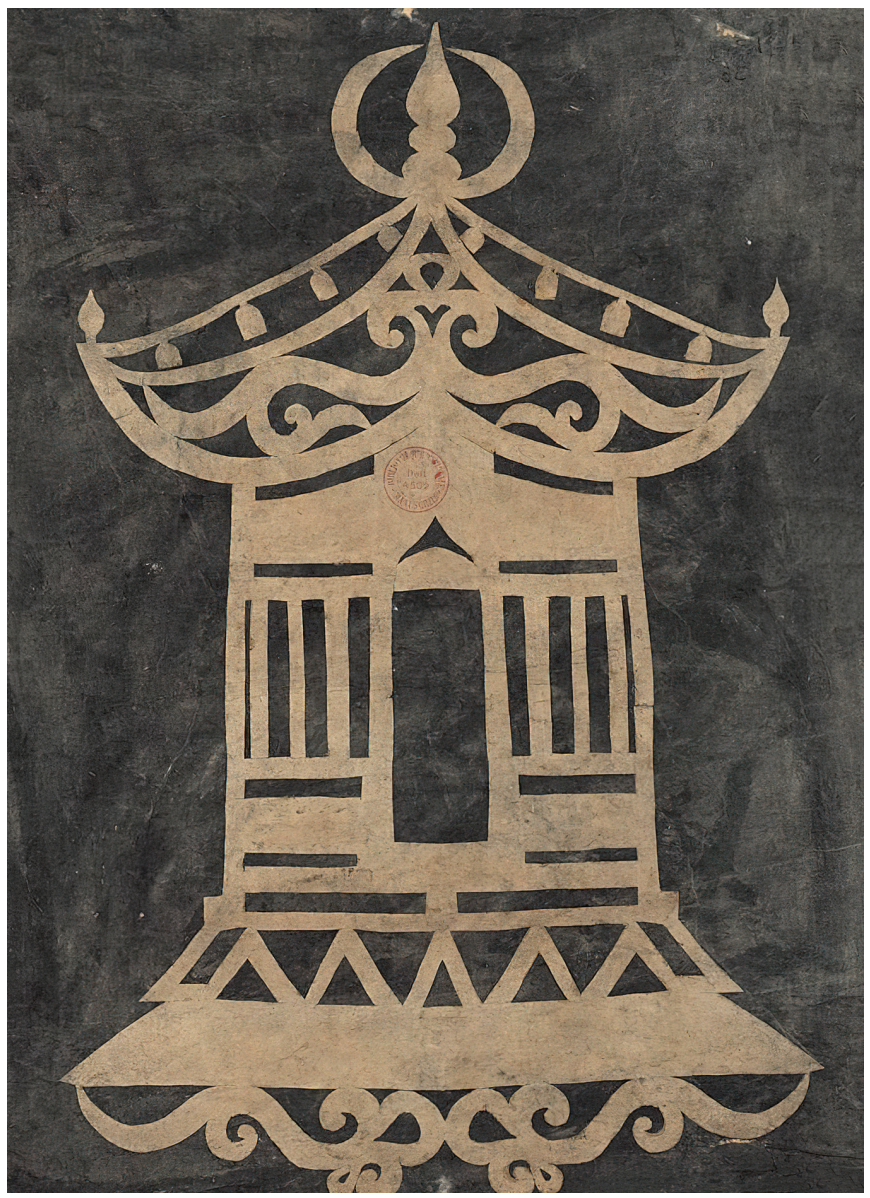

reminiscent of Iranian cut-out specimens, since the motif pasted on a sheet of paper painted in black offers a contrasting two-dimensional graphic effect. A wooden stick on the lower edge and two holes in the upper edges allowed the object to be hung, like a kind of banner, on the cave wall. ${ }^{7}$ The construction evokes the pavilions located in the background of the paradise on the murals. The volutes on the roof and under the base of the stupa are intended to symbolise a transcendent world. ${ }^{8}$ But the interesting aspect is that the cutting method is clearly visible in this article: the sheet of paper was folded in half vertically and then cut with a pair of scissors or a penknife. The resulting product exhibits perfect symmetry in the two unfolded halves, including small accidents left by the blade.

As for the possible origins of découpage from bookbinding, the first illustrations of primitive leather filigree, dating from the eighth and ninth centuries, were fragments of Manichaean bookbindings excavated in the Turfan caves in Xinjiang (Ohta, 2012: 73-291). ${ }^{9}$ The most relevant example is a fragment of an envelope flap in the Museum of Indian Art in Berlin, which shows openwork leather in the form of a filigree with an underlying gold leaf applied to a paper backing. The cut-out design in the shape of a geometric composition features repeating patterns of indented dots framed by a strip of perforated holes. ${ }^{10}$ Then, the transmission of leather craftsmanship and decorative techniques specifically to Coptic and Arab bookbinders took place in parallel with the spread of Manichaeism to the western Mediterranean world and the western part of China (Gulácsi, 2005: 6, 31, 85).

Formal similarities with their Manichaean counterparts are indeed found in book covers from the Coptic period. In a binding fragment from the Musée du Louvre (Fig. 3), there is no paper background, unlike the aforementioned Manichaean fragment, but
FIGURE 2

Stûpa sans étage, Dunhuang, tenth century, Bibliothèque Nationale de France, Pelliot chinois $4518\left(3^{8}\right)$ (C) $\mathrm{BNF}$ 
FIGURE 3

Fragment of a Coptic book cover, Egypt, MAO 26672 a.

(C) MUSÉE DU LOUVRE, DIST. RMN-GRAND PALAIS / CLAIRE TABBAGH

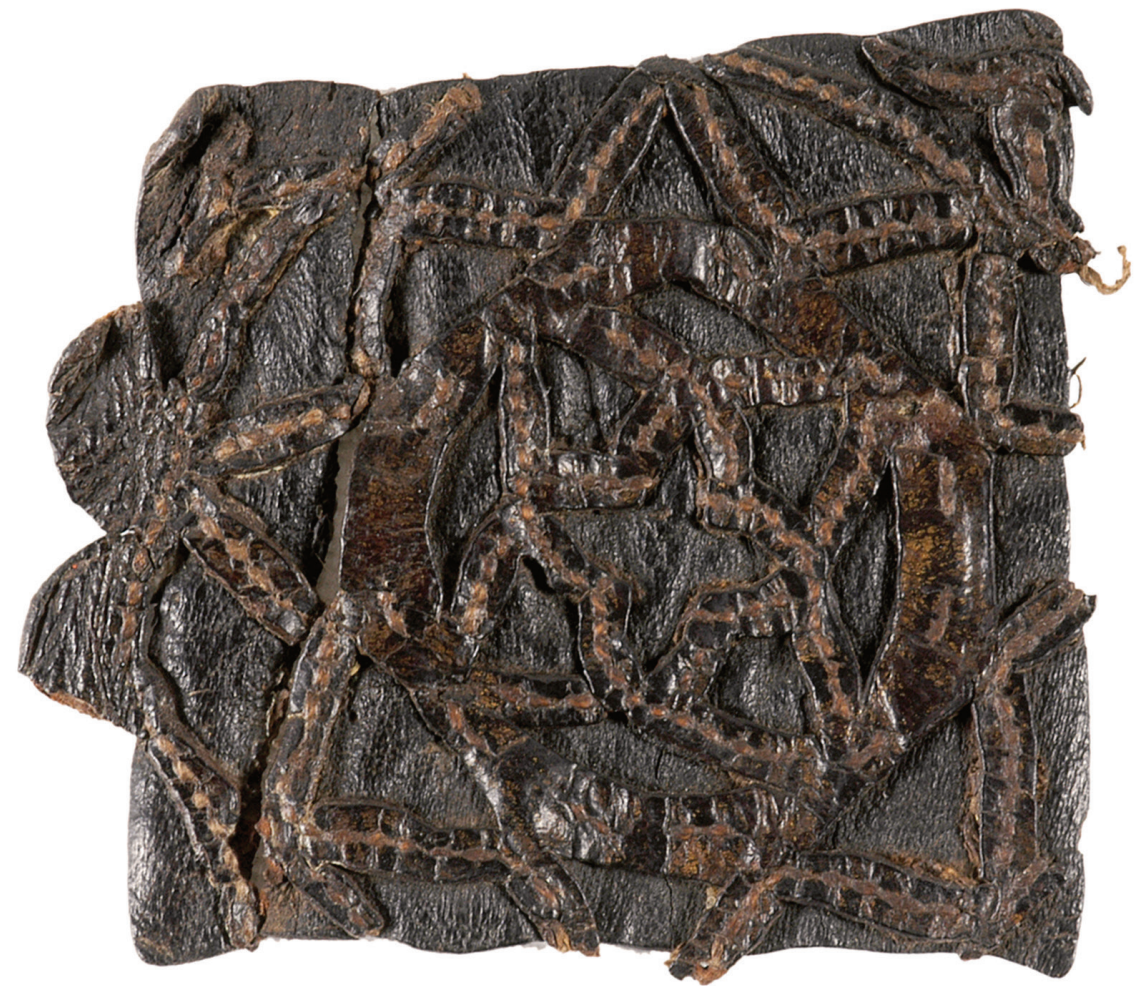

rather an applied filigree panel, cut from a single piece of dark leather, sewn directly onto a leather board..$^{11}$ The cover illustrates an early use of appliqué filigree in the Middle Eastern book culture.

Later, in the second half of the fourteenth century, leather filigree appeared on the covers of Mamluk books in a more accomplished form. For instance, the boards used to protect a juz' of the Quran, dated circa 1382-99 and conserved at the BNF, are decorated with leather filigree work laid onto a green silk ground in the central medallion and the cornerpieces. ${ }^{12}$

After almost a century of abandonment, leather filigree regained its popularity in the latter part of the fifteenth century, during the reign of Sultan Qaytbay (r. 1468-96), with a new impetus given by the artisans from the court of Sultan Ahmad Ğalāyir (r. 1382-1410) (Ohta, 2004: 268). The techniques were also developed at the court of the ruler of Bagdad and Tabriz between 1380 and 1410, alongside the production of filigree binding in the Mamluk Empire (Çağman, 2014: 28). The design is sometimes called monabbat-kārī, a term which refers to relief work found in metalwork and is associated with the technique of pressure-moulding. ${ }^{13}$ Information about the production process is scarce, the design being either produced by a metal stamp or cut with a knife or scissors from a stencil. The decorative method consists of fine motifs cut from red, brown, black or gilded leather, pasted on a background of coloured paper, leather or textile. Leather filigree was mostly used on the inner side of the boards, the doublures, to heighten the insides of recessed mandorlas, medallions and cornerpieces. Mamluk leather filigree was mainly geometric forms, vegetal scrolling and palmettes, whereas the iconography in western Iran featured living beings, plants, animals and mythological creatures. It is not known to which of the two artistic circles the primeur of the invention or of the first use goes; however, the découpage technique was certainly maintained and stimulated by the bookbinders' movements between both courts and their interactions with each other. With Sultan Ğalāyir's death, his artists migrated to the west, to Egypt, or to 
eastern Iran. In Iran, they found patronage at the Timurid workshops where the design technique reached new heights of virtuosity.

Under the Fatimid dynasty, alongside the development of leather filigree, paper was cut to form designs or models and was also used for calligraphy. The Austrian National Library in Vienna holds three fragments with Kufic inscriptions enhanced with geometric bands and palmettes. ${ }^{14}$ One of them, a long strip of paper ending in a triangular shape, includes the name of 'Abdallāh b. 'Itr in Kufic framed by two bands of repeating circular devices (Fig. 4). ${ }^{15}$

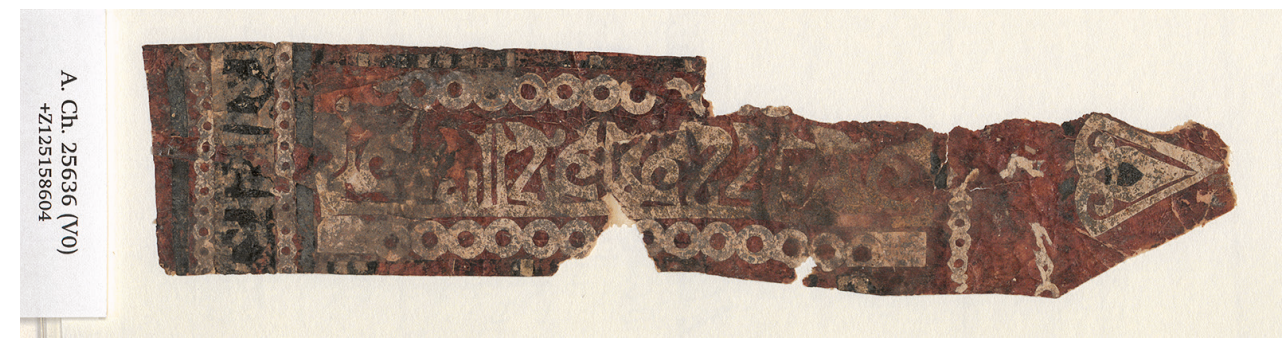

The elements were cut from a now very worn white paper and applied to a paper background with reddish brown tones (Seipel, 1998: 94-5). These designs may have been used as models for textiles, wood or leather. The Metropolitan Museum of Art in New York has very similar items in its collections: two long fragments with triangular endings have similar Kufic calligraphy with a decoration of palmettes and framing bands. ${ }^{16}$ Another fragmentary and rectangular piece shows, on a plain background, a repeating design, cut from brown paper, of six pointed stars from which a geometric interweaving departs. ${ }^{17}$ With these stylised geometric motifs, the specimen resembles cut-out and sewn appliqué leather found in in Coptic bookbindings. But it is most likely that this piece was used as a doublure for a book cover, as the geometric pattern indisputably resembles the blind tooling leather decoration that was later used in Mamluk bookbinding.

Much later but not less interestingly, Prisse d'Avennes mentions that paper "découpures" were made in various colours to decorate the walls of private houses and recall the stucco laces of the Moorish architecture (Prisse d'Avennes, 1877: 198). ${ }^{18}$ The specimens were cut twelve at a time with a penknife and were adhered to paper grounds, sometimes coloured in silver or gold. These were substitutes for painted panelling, much more affordable for the modest classes. Nevertheless, it seems that no physical items have reached us today. There are a few reasons why this could be. First, these productions were certainly considered to be ephemera, cheap surrogates for solid architectural ornaments, which were not meant to be kept but frequently changed. And, secondly, we can easily imagine the vulnerability of such large paper decorations, which probably did not survive the hazardous climatic conditions and exposure to light and other harmful intruders. Although these specimens seem far from the luxurious and unique cut-out Iranian calligraphy, they still illustrate the taste for and craftmanship of paper ornaments through the course of time.

Thus it is in western Iran, during the second half of the fifteenth century, that the découpage art form eventually becomes an art in its own right. Bookbindings produced in Turkmen workshops started to feature paper as a filigree material (Çağman, 2014: 31). ${ }^{19}$ During the sixteenth century, a complete shift took place and filigree was no longer made out of leather but of paper, which was toned or gilded to imitate the gilded leather. Using leather was very time-consuming since it had to be pared extremely thinly so as
FIGURE 4

Cut-out paper, Fatimid Egypt, tenth century, P. Vinob. Ach 25.636, National Library of Austria

(C) PAPYRUSSAMMLUNG ÖSTERREICHISCHE NATIONALBIBLIOTHEK 
not to protrude too much from the surface of the board. Moreover, at that time, books and bookbindings were becoming consumer goods, affordable and accessible to a new class of emerging patrons. Paper filigree was both cheaper for commissioners and easier to prepare for bookbinders.

In the same period, diplomatic gifts in the form of papers, paintings and other luxury goods were offered by the Ming emperors to the Turkmen and Timurid courts and travelled from China along the silk roads. These were the vectors that allowed new paper decorative techniques, such as dying, marbling and gold sprinkling, to be transmitted to Iranian craftsmen (Blair, 2000: 27). Nonetheless, unlike the exquisite Chinese decorated papers utilised for the production of luxury manuscripts, there are no written records or material evidence of Chinese papercuts imported and reused in Iranian books, to the best of my knowledge. ${ }^{20}$ While several works have explored the influence of Chinese models on fifteenth-century Persianate paintings, none have highlighted the possible presence or influence of Chinese papercut specimens (Yusen, 2018). ${ }^{21}$

Yet the découpage technique began to transcend book covers to occupy noticeable spaces within the albums and to become an art form of its own. There are no historical sources narrating the transmission from leather to paper and it is not known how the transfer of knowledge between the materials occurred. However, since bookbinders, calligraphers, painters and illuminators worked in the same artistic milieu, it is most likely that competencies, innovations and ideas were shared among them. Çağman (2014) has thoroughly studied the first developments of the découpage art form from a stylistic point of view. She abundantly commented on two prodigious works produced at the Turkmen courts: an album held today at the Topkapı Palace Museum library (H.2153) and a copy of the Sad Kalima from the Museum of Turkish and Islamic Art in Istanbul (TIEM, 2474). The first album constitutes an inestimable répertoire de forme of cut-out motifs, animals, mythical creatures and calligraphy, and crystallises the syncretism of various sources and influences (Çağman, 2014: 42-84).22 For some of the smaller designs, such as trees and arabesques, the paper was folded vertically in half and cut to achieve perfect symmetry on both sides of the specimens (Çă̆man, 2014: 68-79).

As for the copy of the Sad Kalima, it is the first work for which the cutter and the date are known: Muhammad b. Sayyid Aḥmad b. 'Alī al-Ṣūfĩ al-Mārāḡì in 1471-2. ${ }^{23}$ Again, the album was extensively studied and commented on by Roxburgh (2013) and Çağman (2014); however, it is interesting to highlight here some of the technical aspects that are relevant to this research and will be discussed later, such as the positioning of the letters on the page and the cutter aids (Çağman, 2014: 57; Roxburgh, 2013: 168-9). ${ }^{24}$ Throughout the folios, the diacritical dots and the vocalisation signs in the monumental calligraphies are attached to the body of the letters with discreet but noticeable paper ligatures, indicating that the design was cut and detached all at once from a single sheet of paper. The same type of paper bonds is encountered in some of the calligraphies from the album H.2153 (Çağman, 2014: 44-50). ${ }^{25}$ Should we see in these elements some minute aids for the craftsman? An intermediate step in the technical conception of these works towards a freer or a more controlled process? A search for a visual rhythm in the composition or a practice fashionable at that time? Answers vary. Roxburgh (2013) highlights the non-functional aspect of this "technical scaffold" as a demonstration of the artist's sheer skill. Çağman, on the other hand, points to the difficulties faced by the cutters, mostly Shia Muslims of Central Asian origin, in mastering the Arabic language and their need for technical aids to place letters accurately on the page.

The current consensus within the community of scholars tends to ascribe the origins of the art to Egyptian craftsmen (Bloom and Blair, 20o9). ${ }^{26}$ In terms of style and technique, Iranian cut-out calligraphy is comparable to the aforementioned cut-out Kufic calligraphy in that both have the outlines cut out of light paper and pasted to a darker 
background. There are also no extant examples from China which show the application of cut calligraphy on another paper background. Most of the specimens that remain are loose, volatile, ephemeral laces of paper meant to be offered or hung, in order to bring fortune and wealth and to express emotions. As for the papercut technique's journey from the Turfan Oasis to the Herati court, passing through Egypt, Baghdad and Shiraz, the underlying question is whether we see exchanges of artistic practices or simply a concordance of artistic thought processes and manual practices. Artists travelling from one court to another, following a new patron, or seeking new means of subsistence, were likely the key to the dissemination of découpage on leather or paper. For example, the bookbinder Qivamaddīn, who executed filigree covers for the Jalayrid ruler Sultan Ahmad in Baghdad, moved to Herat to work under the patronage of the Timurid princes Bāysungiur (1397-1433) and Shāhruhr (1405-47) for whom he executed splendid bindings with the similar decorative method. ${ }^{27}$ Shortly thereafter, papercutting took a new turn at the Herati court during the reign of Sultan Husayn Bāyqaāa (1470-1506). Therefore, it is likely that at first there was a sort of transition period when the bookbinders were also in charge of papercutting, until a new category of artists, the cutters, took over.

\section{Tools and Techniques}

\subsection{Tools and Cutting Implements}

One of the objectives of this research project was also to better identify the tools used to carry out this work. Zokā wrote a chapter on this matter in his essay (Zokā, 200o: 145). Nevertheless, due to the scarcity of information in modern or ancient sources, Chinese works have also been consulted to provide additional guidance on production processes (Warner, 1978; Zhang, 1989).

According to Zokā (2000), the tools are simple and rather limited. ${ }^{28}$ White or coloured paper, kājaz, كاغذ, of course, was the main material, neither too thick nor too thin, as it would be difficult or even impossible to cut. Nothing is mentioned about the type of paper used, its quality, thickness, composition, and so on. The scissors, called meqräz;,

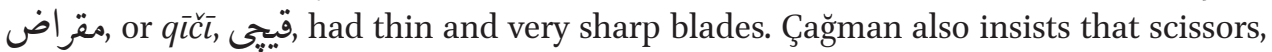
called mikrāz, were the main cutting instrument used by Ottoman artists (Çağman, 2014: 15). Different types of knives were also part of the cutter's tools: a small knife with a thin and sharp blade called kārd, ك, the gazan, 5 , a kind of paring knife with a half-moon blade, and the shefrah, شفرد, with a thin and fine blade, used to cut leather. Various "iron qalams" with sharp tips and special shapes were employed to cut curves, arcs, circles and to carve small holes. These were certainly related to the awls or chisels which were also commonly used by bookbinders and silversmiths. The Topkapı Palace Museum Library has a kind of chisel with a long ivory handle terminated by a spear-like pointed tip (Fig. 5), inventoried as yazi keskisi, which can literally be translated as "cutter for writing" or, in other words, a tool to cut inscription. ${ }^{29}$

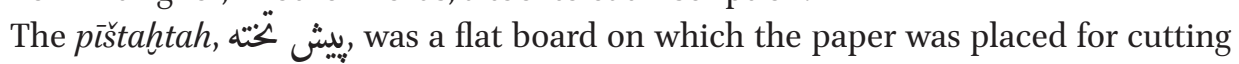
out holes, curves and internal parts of a specific design with the iron qalam which, in combination with a hammer, was used as a chisel. ${ }^{30}$ The last tool was the cardboard or moqavā, مقو, the support made up of several sheets of laminated paper. After the cut was complete, it was laid on a coloured or tan moqavā, not only to secure it and prevent further damage, but also to make the cutting design clearly visible.

Zokā (2000) does not specify the source of the above tool list; however, many names come from instruments used by Arabic bookbinders. We have seen that the filigree paper technique came in part from leather filigree binding, so it is not impossible that

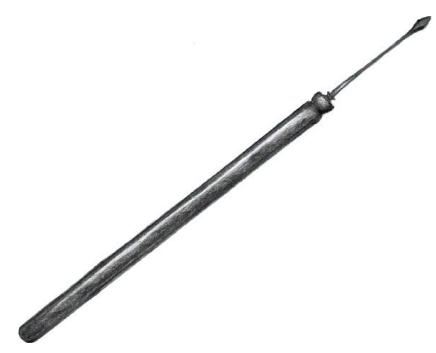

FIGURE 5

Reproduction of the cutting tool called yazi keskisi, preserved today at the Topkapı Palace Museum Library (C.Y.438)

(C) A. COUVRAT DESVERGNES 
some of the tools of the bookbinder and gilder, such as shears, scissors, knives and awls, were borrowed by the cutter from his peers. ${ }^{31}$ Similar equipment is found in ancient treatises in Arabic. Al-Qalqašandī, Ibn Bādīs and al-Sufyānī reported different kinds of

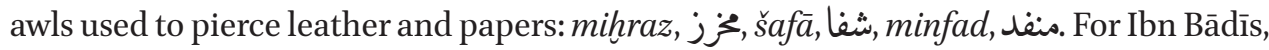
the šifra, شيفرة, is a paring knife with a half-moon blade, and the miqașș, مقنص, are the scissors used to trim leather or other materials (Bosch et al., 1981: 43). In addition, Ibn Bādīs mentioned two types of press: the first, used in Iraq, Egypt and the Khurasan, is tightened by a rope, and the second is a screw press used by Iraqi and Byzantine craftsmen (Bosch et al., 1981: 42). However, the use of presses does not appear in Zokā (2000). Nevertheless, after close observation of the studied folios, it seems very likely that the cutter required a press to apply a certain amount of pressure to the finished piece to ensure that the letters adhered correctly to their support. This point will be discussed later in the paragraph dedicated to the Louvre album. Most of the current collections of calligraphic tools from Turkey or Iran are dated from the nineteenth or twentieth centuries. These hold two types of scissors and knives: long scissors and knives used for cutting paper sheets or for sharpening the qalam, and short and sharp scissors and penknives with small and thin blades, more suitable for the task of cutting design and letters (Roxburgh and McWilliams, 2007: 11, 19, 20, 29). In Zokā's essay there is a photograph of the cutter Mīrzā Aḥmad Tehrānī, taken in 1916 (Zokā, 2000: 147). He is seated at a table displaying his calligraphy and that of his fellow cutters. Armed with a small pair of short-bladed scissors, he is about to cut a piece of paper.

\subsection{Theoretical Overview of the Cutting Methods}

Zokā (2000) mentions some noteworthy aspects of the cutting method. There are two such methods: free cutting and cutting from a model. The first does not involve a model but relies solely on the artist's dexterity. The cutter cuts a pattern directly from a sheet of paper, exercising his imagination and skill. To cut calligraphy, he does not necessarily make a preliminary outline but carefully observes a model and then reproduces it freely and without help. In some specimens, the master of the gesture and the artist's skill are such that the positive and negative parts form two separate but complementary entities which are kept as two distinctive specimens. In the Chinese context, Zhang advises to "follow the scissors" and to "proceed from the inside out and from thin lines to thick lines, ending with the outline" (Zhang, 1989: 58).

With the second method, the cutter follows the model dictated by the calligrapher. First, the latter makes the composition on a sheet of plain or coloured paper, then the cutter carefully cuts each letter using scissors or a penknife and pastes them on a thick paper support. These specimens highlight the collaboration which took place between the calligrapher and the cutter. Through examples of signed découpage works, as we will see in the next paragraphs, we notice recurrent pairs of artists working together. It is difficult to say if such collaborations were due to workshop rules, decisions of the kitābkhāna head, professional complicity or connivance between two co-workers or simply the scarcity of cutters. However, we can note that the name of the cutter was often joined to the calligrapher's, meaning that they enjoyed similar levels of recognition.

Finally, Zokā (2000) describes the assemblage method: first, the background paper is slightly moistened and covered with a layer of paste. Then the cut pattern is applied on it. To ensure that the design adheres properly to the backing and to absorb any excess moisture, a sheet of dry paper is placed on top and the whole thing is flattened with a palm fibre brush. This detail is important since some assumptions about the mounting process will be mentioned in the conclusion. 
The studied specimens feature positive cutting as described in the first part of the paper. It is relevant to point out that the first two works, from the MIA and the Rijksmuseum, respectively, are small and epitomise the taste for manuscripts of reduced formats in this time period and geographical area. ${ }^{32}$ The third work of the corpus is a concertina album of twelve folios which was remounted during the Qajar era.

\subsection{Two Folios of the divān of Sultan Husayn Bāyqarā}

The two folios from the Museum of Islamic Art of Qatar (MS 809.MIAQ and Ms.81o. MIAQ) show the starting point of the art of calligraphy by cutting in Iran (Fig. 6).

They belonged to a now dispersed dīvann whose ghazals were composed around the 149os in Chagatai Turkish by Sultan Husayn Bāyqarā himself. While the finispiece is now regrettably missing, most of the corpus is now kept in Istanbul: thirty folios are currently preserved in the Turkish and Islamic Arts Museum and another fifteen in the Topkapı Palace Museum. ${ }^{33}$ Among these is a page that features the name of the cutter, 'Abdallāh Herāvī; the name of the calligrapher, Sultan 'Alī Mashhadī, is written on a separate folio. ${ }^{34}$ Regarding 'Abdallāh, Mușțafā 'Alī Efendī says: "His mastery was an indisputable testimony (nașs ) to the extent of his talent and his every découpage line resembled an immaculate sword ... Unquestionably, he was a prince among the masters of the art of découpage [and], with [his] sword, he was possibly their celebrated captain."

Sultan 'Alì Mashhadì's career and the manuscript have been well documented so the context of production will not be further explored here. Other collaborative pieces signed by both masters are preserved today at the Central Library of Āstān Quds Rażavī in Mashhad ${ }^{35}$ and at the Topkapı Palace Museum Library in the Bahrām Mīrzā album. ${ }^{36}$ However, while previous works have detailed styles and art history, none has yet delved into production techniques. ${ }^{37}$ Through the corpus, we encounter different coloured papers used for the background: blue, blue green, off-white/cream and ochre. Pasted
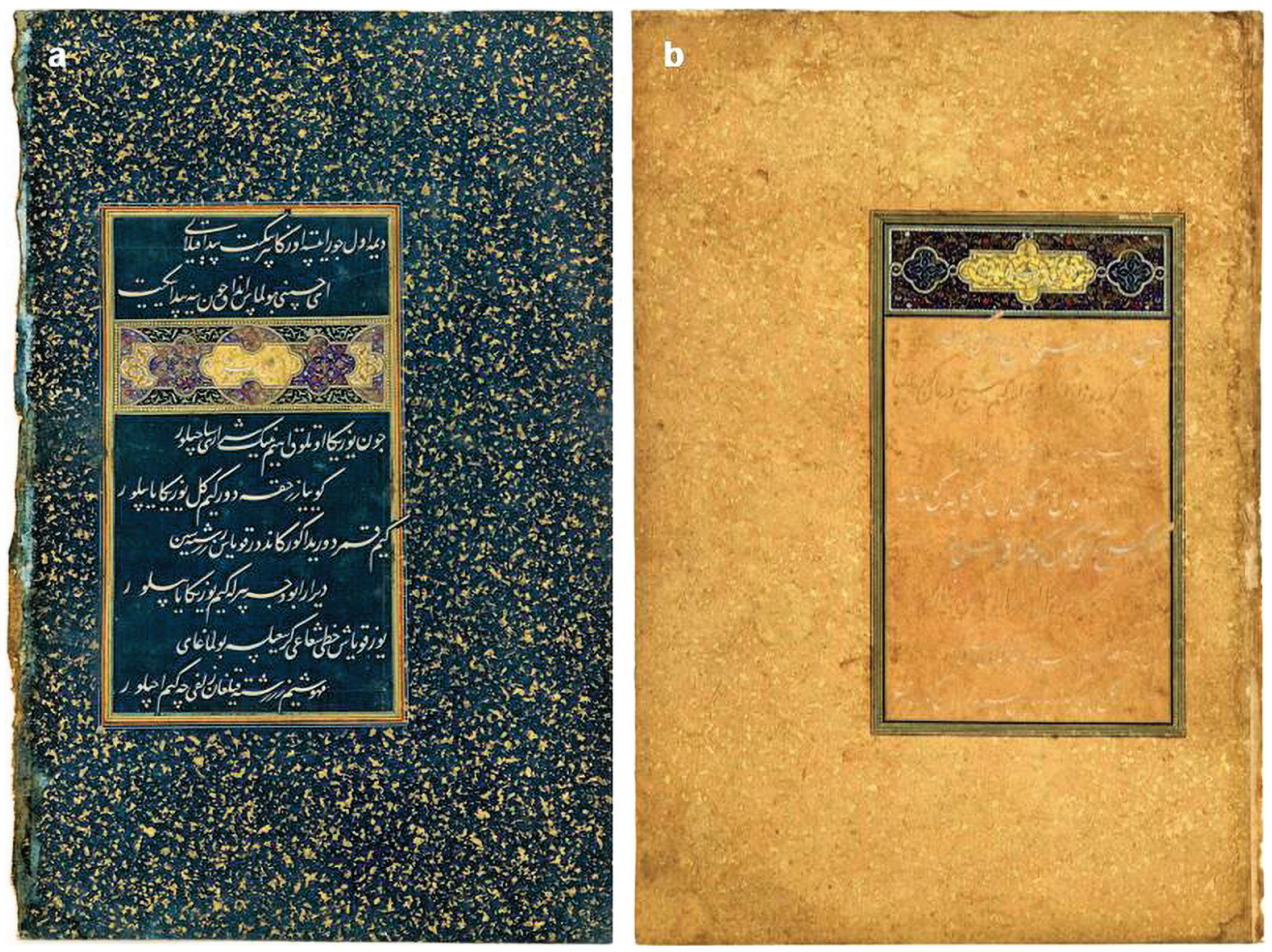

FIGURE 6

Two detached folios from the dìvān of Sultan Husayn Bāyqarā (c. 1490): a. MS.809.MIAQ; b. MS.810.MIAQ, Museum of Islamic Art, Qatar (C) MIA 
FIGURE 7

Micrographs of Ms.8og.MIAQ and MS.810.MIAQ: a. extension of the letter in the border; b. the ruling serves as a support for pasting of the cut-out letters

(C) A. Couvrat DESVERgnes on these grounds are lines of text cut out of subtly coloured papers: off-white, pale blue, salmon pink or cream. In the folios without headings, there are strictly ten lines of text. When an illuminated title is present, there are only eight lines of text because the heading occupies the location of two lines. The verses are arranged in staggered rows of various hues to give a visual rhythm to the whole composition. As underlined in several works, the manuscript is distinguished by the minuteness of the letters and the extraordinary refinement of the execution (Roxburgh, 2013: 171). Close-up observation of the front and back of the Doha folios using a stereomicroscope reveals that the supports are made from simple sheets of paper with no attached borders (Fig. 7).
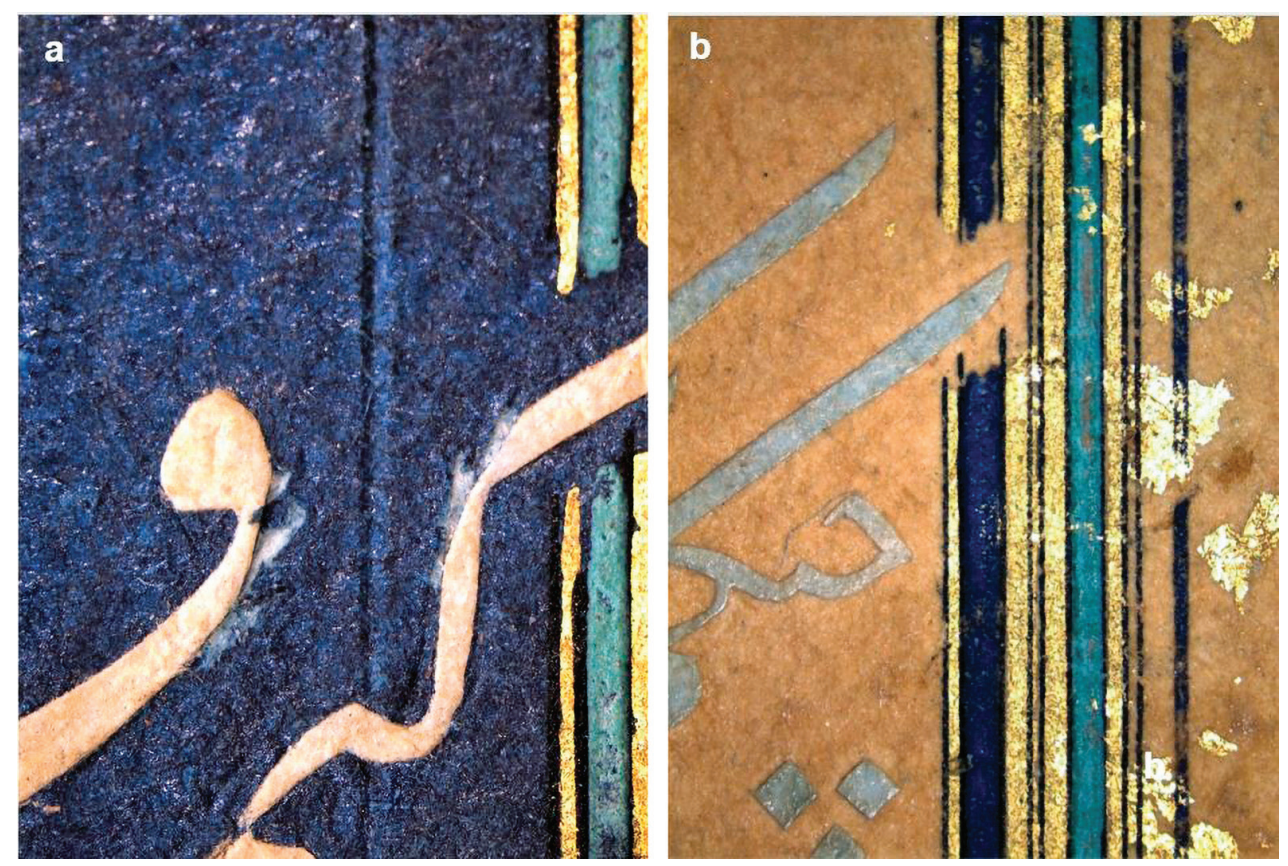

These are decorated with gold particles. The connection between the borders and the text panel is provided by a series of ruled lines and coloured frames. Sometimes a letter stroke goes beyond the text panel and is accentuated by an interruption in the rulings to allow the passage of the stroke. ${ }^{38}$ At first glance, it seems that no guide or network was used by the cutter to position and paste the letters. Scribes often used the mistara, ${ }^{39}$ a threaded board that was pressed with a bone to the paper, to produce the network of ruled lines to be used as a guide. Although some traces are found on most of the folios observed, the lines on this work do not look like ruling per se, but rather an enclosure for the calligraphic panel. Four perforations were pricked with a needle in the four corners of the pages and four lines were marked with a stylus to connect them. The cutter used the ruling from the top, bottom and sometimes the right side as supports to paste the letters, as shown in Fig. 8. 




In some folios, the frames are easily visible while in others they are not. Either they are covered by the series of coloured ruling, or they do not exist. ${ }^{40}$ By looking through the stereomicroscope, we can get a better idea of 'Abdallāh's performance. Many details are not visible to the naked eye, and a closer look sheds light on how the cutter did his work. The contours of some letters were corrected and cut with a knife after being glued to the support. As a result, the notches left by the blade in the background are clearly visible against the letter $v \bar{a} v$ (Fig. 9a). In other places, the letters were altered, and the excesses of paper were scratched away, leaving some whitish remnants of paper on the background (Fig. gb).
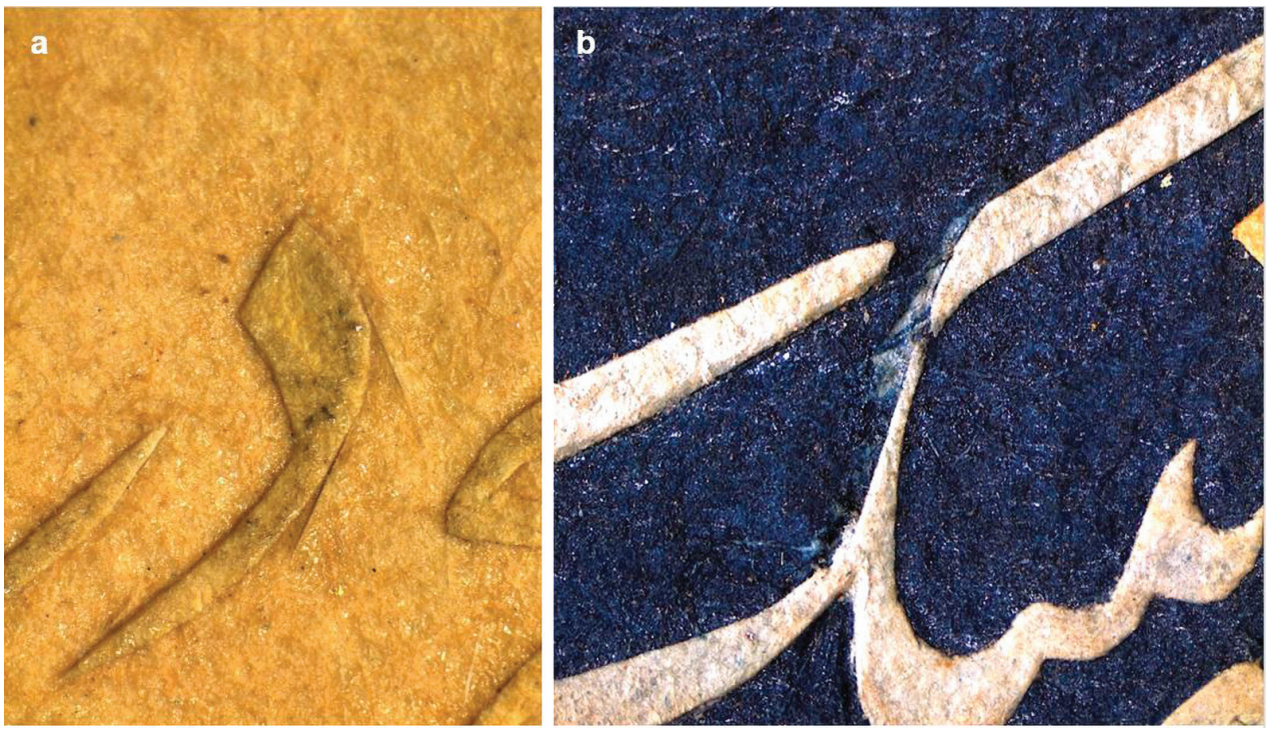

FIGURE 8

The pinhole and ruling, Ms.810. MIAQ

(C) A. COUVRAT DESVERgNes

\section{FIGURE 9}

Corrections in the letters with a penknife to adjust their contours: a. letter $v \bar{a} v$; b. letter $k \bar{a} f$; micrographs from the Doha folios MS.8O9.MIAQ and MS.81O.MIAQ (C) A. COUVRAT DESVERGNES 
FIGURE 10

a. Accidents in the letter ye; $\mathrm{b}$. marks made with a bone folder around the letters $k \bar{a} f$ and alef (C) A. COUVRAT DESVERGNES
Çağman, in her monograph, reproduces two short-bladed knives, dating from the nineteenth century, each described as a "penknife for corrections" (Çağman, 2014: 16). Indeed, this type of knife could have been used by 'Abdallāh to correct his letters. Sometimes, the cutter did not fully control his movement. Consequently, some letter strokes, such as in the letterye from the Doha blue folio (MS.8og.MIAQ), almost came off when the letters were adhered on the support (Fig. 10a). Moreover, some slight marks, difficult to interpret, are found on the ground, around certain letters. Either these are marks left by a tool that was rubbed across the surface to improve the adhesion of the letters, or they are registration marks made with a folder to help place the letters in the correct position. Many of these traces are found on the blue Doha folio, around the letters $k \bar{a}$, mìm, $\sin$, alef and $l \bar{a} m$, while the ochre folio does not show any traces at all (Fig. 1ob). For this reason, we cannot yet draw conclusions on the systematic use of registration marks.
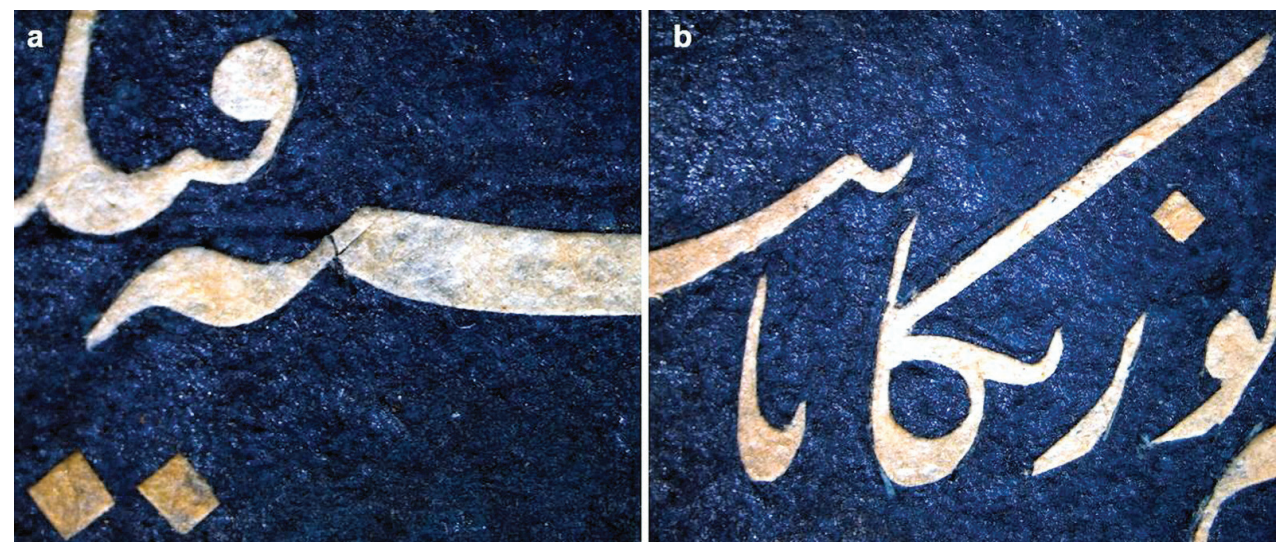

A folio held at the BNF presents a calligraphic panel of some verses from the same dīvann, imbedded into a composite page (Fig. 11a). The inscription "Abū al-Qāsī Sultān Bahādur Husayn Ğān," written with gold ink in the cartouche, might also attest to a Herati origin of the work. Although the piece is unsigned, it contains the specificities of Sultan 'Ali Mashhadì's script and 'Abdallāh's technique. The composition of minute white letters on a dark blue ground and the staggered arrangement of lines recall the format of the aforementioned divinn, although some lines, arranged vertically, are not found in the 149os manuscript. Again, in close-up, the contours of some letters are corrected with a penknife. But each dot has a tiny hole in the middle, as if it was picked up with a pin to be carried from the cutting board down to the page (Fig. 11b). Interestingly, similar technical detail is encountered on both MIA pages. With the Dinolite measuring tool, we were able to measure the diagonal of the square marks as just over a millimetre. Therefore, it is easily understandable that grabbing many minuscule bits of paper and positioning them accurately was a rather tedious job, even for a competent artist and even more so if that task was multiplied by the number of letters and points required for the completion of an entire literary work. The gentle passage of a finger across the surface reveals no bulk, accidents or difference in thickness between the ground and the letters. When viewed close up, the paper is so thin that it is almost transparent, making the underlying dark blue background visible (Fig. 11c). Perhaps we should see in these traits the relevant markers of 'Abdallāh's personal practice? More specimens need to be examined before making such a statement; however, these elements are one more step in the search for marks and patterns of manufacture and provide a better understanding of the découpage technique implemented by an Iranian artist. 


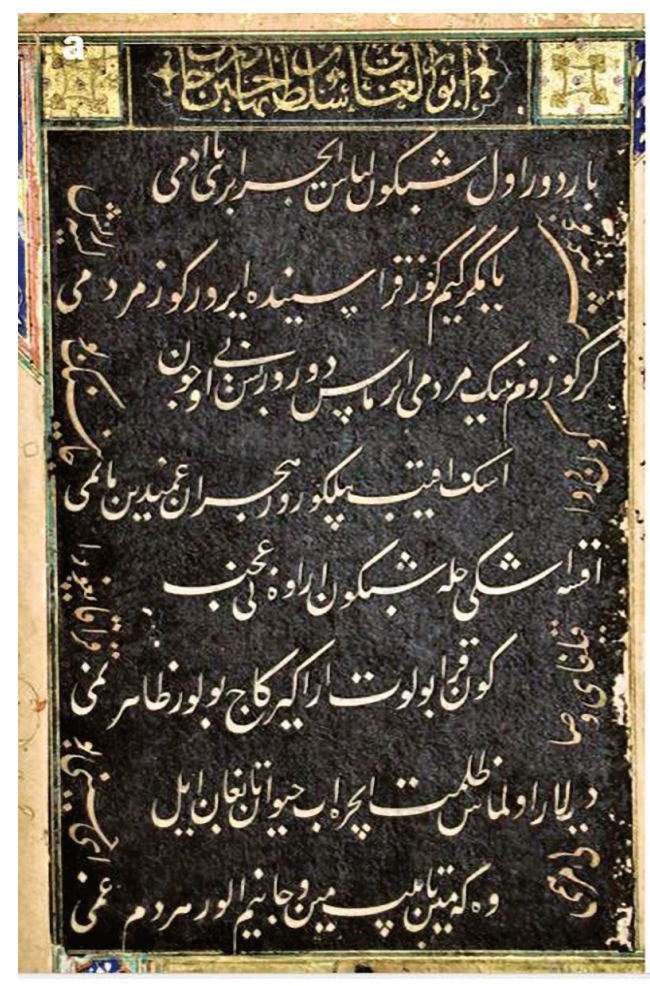

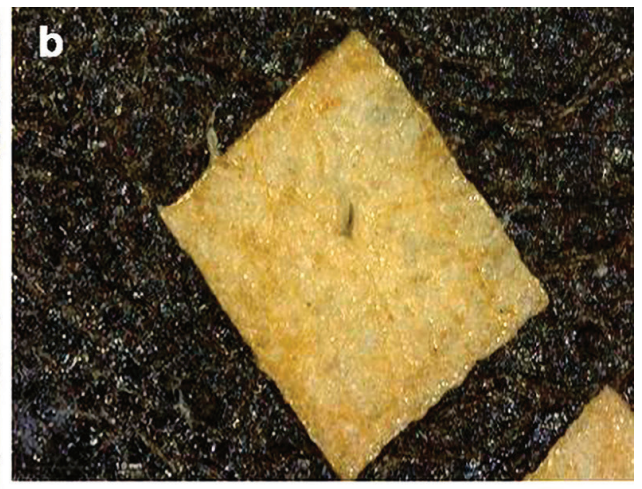

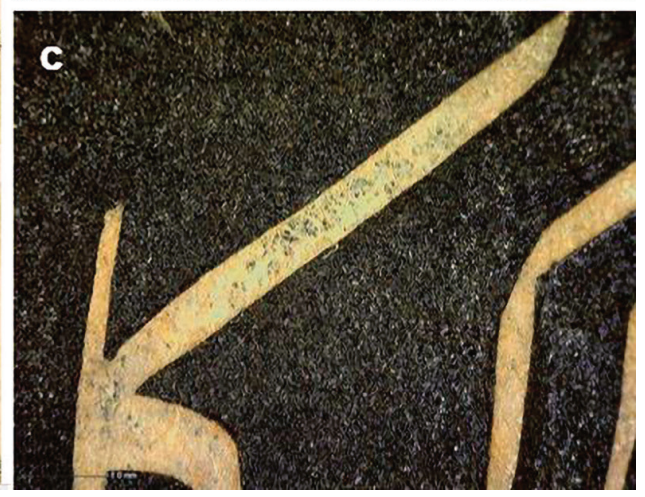

\section{FIGURE 1}

a. Detail of folio 8 from the Supplément Persan 1954; b. and c. micrographs of the dot and the $k \bar{a} f$, respectively

(C) A. COUVRAT DESVERGNES

\subsection{A Folio Signed Ḥẫfez BābāJān and Dūst-Mohammad}

The second work of the study is a double-sided folio from the Rijksmuseum in Amsterdam. ${ }^{41}$ The recto depicts a full-length portrait of a courtier in Qazvin style and the verso displays two verses of ghazal no. 284 from Ḥāfez (Fig. 12). ${ }^{42}$

The two first lines in the upper part of Fig. 12b recto read previously: "O Ḥâfeẓ! if union had been attainable, all the time"

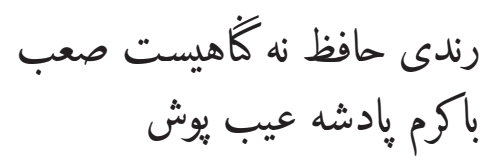

They were made in découpage but the letters are now missing and only a few dots are still in place today. The lower part of the folio, written in white ink, reads: "the text is written by the humble and pious ... Jān and cut by Dūst-Moḥammad, the poor sinner, may God forgive his sins."

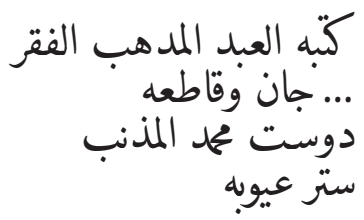

A calligrapher's name ending with Jān is not very common and we can assume that the artist is Bābā Jān Horāsānī (d. 1537). He was the son of Hāfez 'Abd 'Alī Torbatī, a religious figure who belonged to the court of Sultan Ḥusayn Bāyqarā and the brother of Ḥâfez Qāsim, a famous singer. Bābā Jān was an artist of many talents, a calligrapher, a poet, a craftsman and a renowned oud player. But despite his diverse skills, the scope of his activities remains obscure and his existing works are very few. From Herat, he possibly moved to Qazvin where he worked for Shāh Tahmāsp and then for Bahrām Mīrzā. He may have participated in the preparation of the latter ruler's album although he is 
FIGURE 12

a. Portrait of a man in a red robe playing a musical instrument, RP-T-1993-462 (R); b. calligraphy specimen with cut-out verses, RP-T-1993-462 (V)

(C) RIJKSMUSEUM, AMSTERDAM
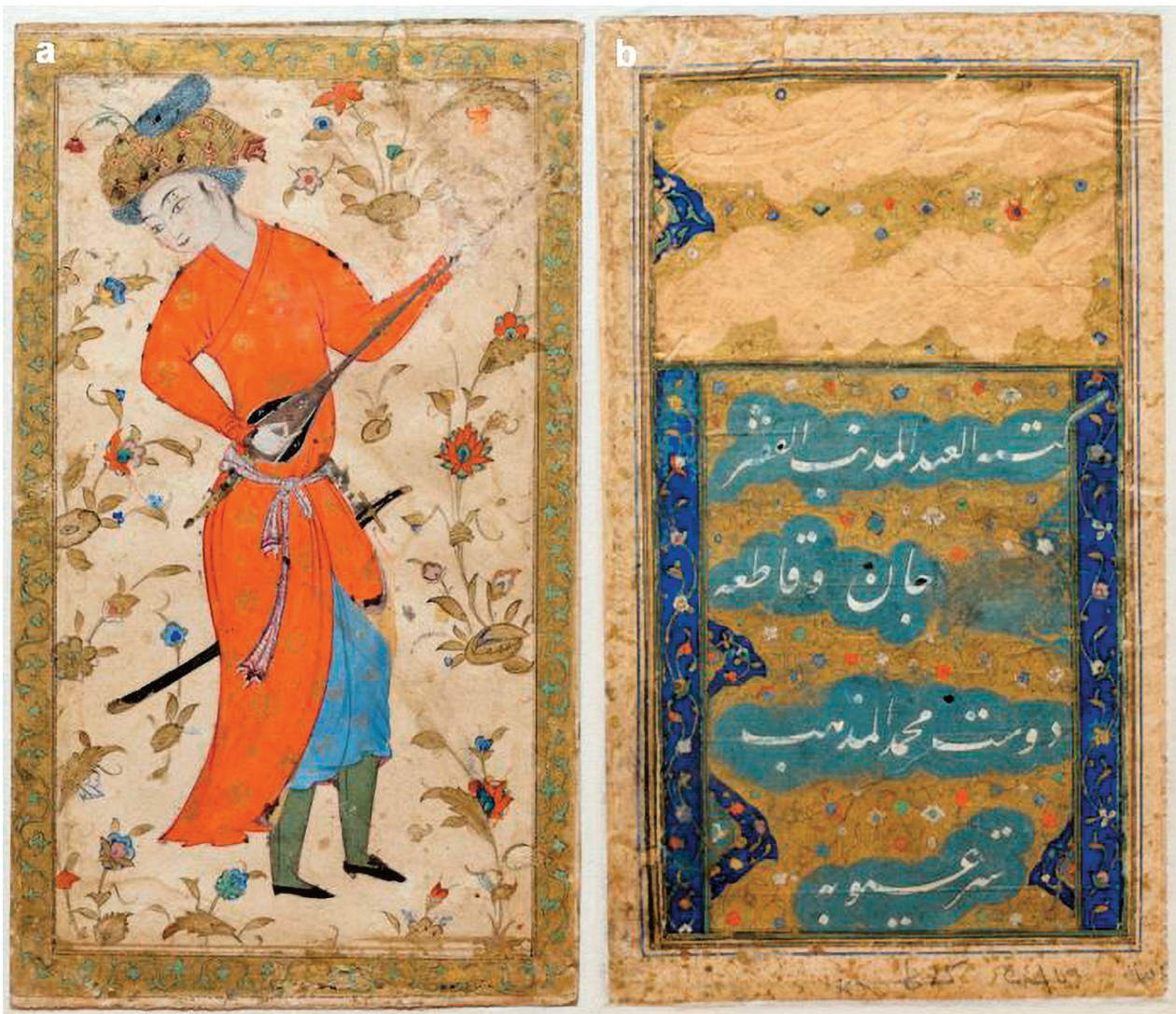

not mentioned in the preface written by Dūst-Mohammad. ${ }^{43}$ Nevertheless, since Bābā Jān died in 1537, it is likely that the folio was produced within the first four decades of the sixteenth century. ${ }^{44}$ Ghazal no. 284 was originally composed of nine verses of two hemistiches each or eighteen lines of text, so it is certain that the original work consisted of two additional folia or a bifolio. So far, these have not been located in any collection.

Regarding Dūst-Moḥammad, Mușțafā 'Alī Efendī writes: "Then, [there] was Shaykh Moḥammad Dūst Qaț̣i, the aforesaid ['Abdallāh Qaț'i]'s talented son and pupil, a pillar of the arts. He was a man of decorum, [close in rank to his master, and his ability] approached to that of his talented father. Everyone agreed with the maxim 'A child bears the secret of his father,' and [they] had a penchant for his découpage, just as they had for his father's." However, the artist's identity is very much debated and there has been a lot of confusion around several artists of the same name (Dūst-Mohammad): a calligrapher, a cutter and a painter (Adle, 1993) ${ }^{45}$ As for the cutter, four different signatures found on different cut-out specimens are reported by Adle (1993) and Çağman (2014): Dūst-Moḥammad b. Šayh 'Abdallāh ('Abdallāh's son) who, like his father, also cut calligraphy by Sultan 'Alī Mashhadīi, ${ }^{46}$ Dūst-Moḥammad Muṣavvir ${ }^{47}$ and Dūst-Mohammad (with no qualificative, suffix or nisba). ${ }^{48}$ The fourth autograph, with the suffix al-Muzahhib, has also appeared on an illuminated handwritten cornerpiece but not on a cut-out calligraphy. ${ }^{49}$

With the exception of the Rijksmuseum page, the name Dūst-Mohammad al-Muznib (the sinner) has not yet been found on any cut-out calligraphy inventoried. Therefore, the identity of the cutter of this page remains unclear. He could be one of the aforementioned cutters using a different signature, or another cutter, self-proclaimed DūstMohammad, who has yet to be identified. The fact that the four lines of the colophon are written in white ink, now badly worn and partially erased, and not cut, like the verses above, has raised doubts about the authenticity of the authorship. Nevertheless, 




the two cut lines allow us to highlight a particular method which deserves to be studied here. With raking light, we can see that the ruling is made up of six horizontal lines on which the alignment of the letters rests (Fig. 13). The lines were marked with a sharp tool in the background and served as guides for the manuscript colophon and the cutout verses.

The loss of the letters was probably the result of a failure of the adhesive, which had deteriorated over time or was too weak in the first place. When testing the remaining parts such as the dots with a fine brush, these appeared to be extremely mobile and on the verge of falling. The découpage was probably weakened when the front and back of the existing folio were reassembled together. Under the microscope, the diacritics and vocalisation, as in the Doha folios, appear to have small pinholes in the middle (Fig. 14). Close examination also reveals that the pasted letters are at the same level as the paper background. Around the letters and dots, we can see deep cuts in the bottom of the paper made by a knife..$^{50}$ This indicates that the background was roughly carved out, following the outlines of the letters. Then, the cut-out letters were pasted into the carved spaces so that they protruded only about a millimetre from the surface. This method is mentioned by Zokā (200o) without further details about the purpose and reasons for such work. The whole composition seems almost illusionistic, especially because the letters are the same tone and texture as the background paper and do not really stand out. This aspect seems quite confusing. What is the point of such tedious work if it cannot be admired?
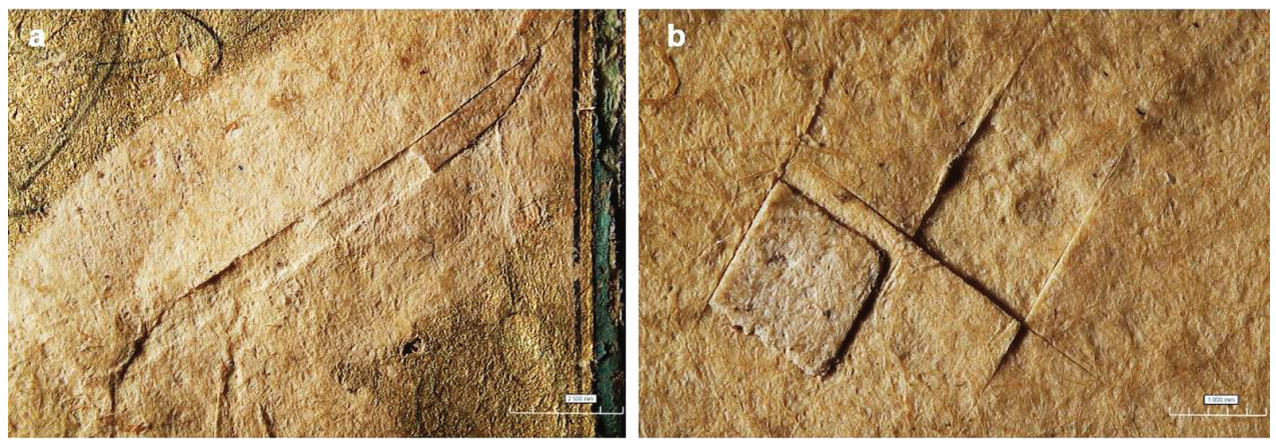

FIGURE 13

The upper part of the folio in raking light intensifies the features of ruling and the inset letters, detail of RP-T-1993-462 (V) (C) A. Couvrat Desvergnes
FIGURE 14

Micrographs taken with the $3^{D}$ digital microscope Hirox-RH 200O, at $20 \mathrm{X}$ and $40 \mathrm{x}$, to highlight the inset method: a. in the partially missing $k \bar{a} f$; b. in the vocalisation dots, the left dot showing a pinhole in the middle (C) A. Couvrat Desvergnes 
FIGURE 15

Verso of a double-sided folio with cut-out letters, Neẓāmī's Mahzan al-Asrār, RCIN 1005047

(C) ROYAL COLLECTION TRUST / HER MAJESTY QUEEN ELIZABETH II 2020

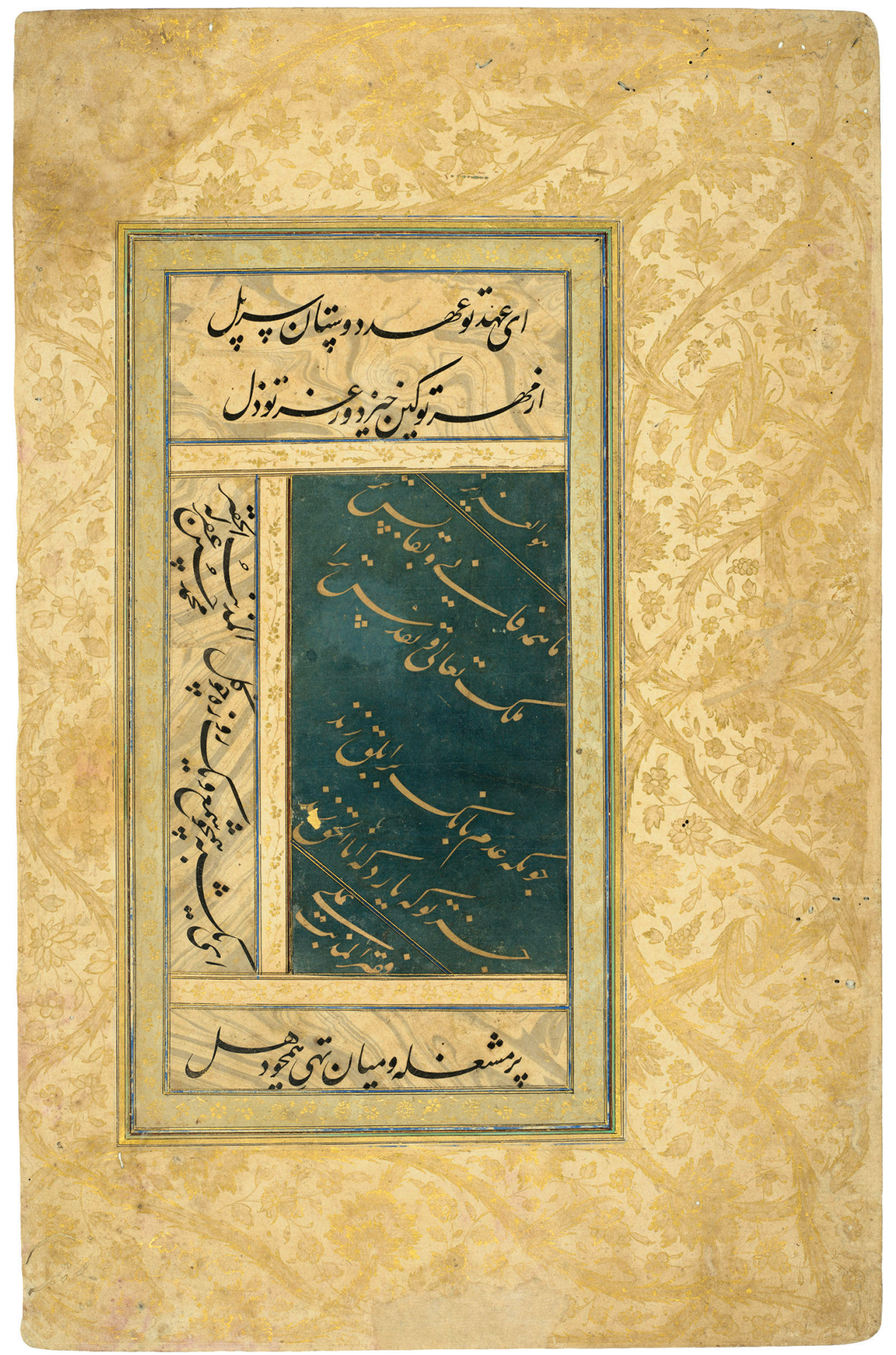

A folio from the Royal Collection Trust in the UK featuring a variation of an excerpt from Nezāmī's Mahzan al-Asrār (Treasury of Secrets) (Fig. 15) also attests to the use of the "inset" technique. ${ }^{51}$

Although the cutter's name is not cited, the page is signed by the calligrapher Mir 'Alī in the triangle at the lower left corner. ${ }^{52}$ The five verses were cut from a pale peachy paper and pasted on a blue paper background. ${ }^{53}$ Again, in the accidents in the letters, the close-up images reveal that, like the Rijksmuseum folio, the contours of the letters were first incised in the blue ground, and then the small letters were pasted into the 
insets. The micrograph of a square vocalisation sign (Fig. 16) highlights two notches left by the knife around the left tip. The letter $v \bar{a} v$, with its missing part, also underscores that the letter appears at the same level as the blue background once it is embedded within the paper substrate. ${ }^{54}$

All these elements indicate that the inset technique, which illustrates a further step in the search for illusionism, may have been implemented to imitate calligraphy done in white ink. This aspect will be underlined in the last part of this article.
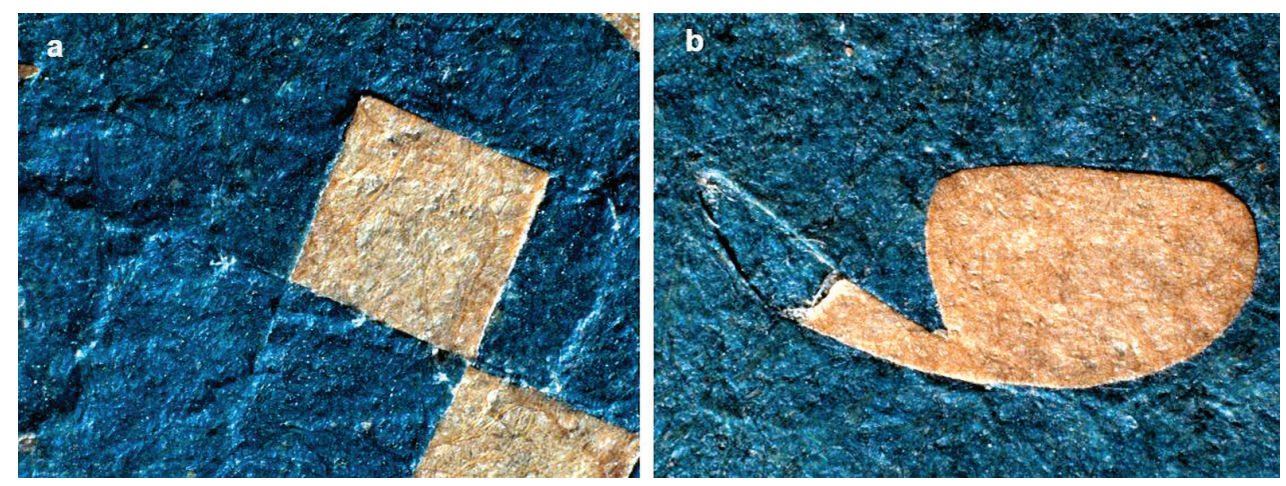

\subsection{An Album of Munājātnāma Signed Mir 'Alì and Sangī 'Alì Badahshī}

The third example is a concertina album containing verses from the Munājātnāma, a text written by Huwājah 'Abdallāh Anșārī in the eleventh century. The twelve pages of the album kept today in the Louvre (Fig. 17) bear witness to remarkable execution and exceptional authorship. The last folio presents, in cut letters, the names of the calligrapher, Mir 'Alī, and of the cutter, Sangī 'Alī Badahshī.

Mir 'Alī's career is rather well documented and will not be detailed here. However, given the biographies of the two artists, it is likely that the album was produced in Bukhara before the 1540 s. Born in 1465 in Herat and raised there, Mir 'Ali worked in the royal workshops of the Timurids and then for the Safavid rulers. In 1528, he witnessed the Uzbek capture of Herat and was forced into exile in Bukhara, where he served 'Ubaydallāh and 'Abd al-'Azīz, khans of the Šaybānīd dynasty until his death around 1544. Sangī 'Alī Badahshī, a highly regarded découpé master, was also employed in the library of the Uzbek ruler. Qāội Ḥamad reports a cutter called Mawlānā Naźr 'Alī Qaṭ̂̄ who originated from Mashhad in Badakhshan and was dressed in a "dervish attire": "Looking at samples of Mir 'Alì's script, he cut out qit'a so that there was no difference and no superiority between what was written and what was cut out ... He settled down in Holy Mashhad and many people studied under him and imitated him but could not equal him" (Minorsky, 1959: 193). Referring to this description, Çağman assumes that the artist was Sangī 'Alì Badahshī, the same artist who cut the letters of the Louvre album (Çağman, 2014: 94). Regarding the latter, Mușțafā 'Alī Efendī writes: "[There was] also Sangī 'Alī of Badakhshan, a pupil of the painter Dūst-Mohammad. He was a world master and his découpage was prized and considered unrivalled in all lands. The finesse of his cut-out lines surpasses what the reed pen [can] produce, and the elegance of his outlines cannot be created with traces of ink" (Akın-Kıvanç, 2007: 264-5). He is also cited in Shams al-Dīn Moḥammad Wașfî’s preface to Shāh Ismācīl II's album as a découpeur and listed under the calligraphers of Shiraz and Kirman (Thackston, 2000: 33). ${ }^{55}$ If several specimens bear Mir 'Alì's name in cut-out letters, the name of the cutter does not appear on the pages. ${ }^{56}$ However, a few works highlighting the collaboration between both masters are little known and remain unpublished: a sheet in a negative form from the Bellini album held today at the Metropolitan Museum of Art, a folio from
FIGURE 16

Micrographs of the inset technique: a. in the diacritics; b. in the $v \bar{a} v$; RCIN 1005047 (C) ROYAL COLLECTION TRUST / HER MAJESTY QUEEN ELIZABETH II 2020 

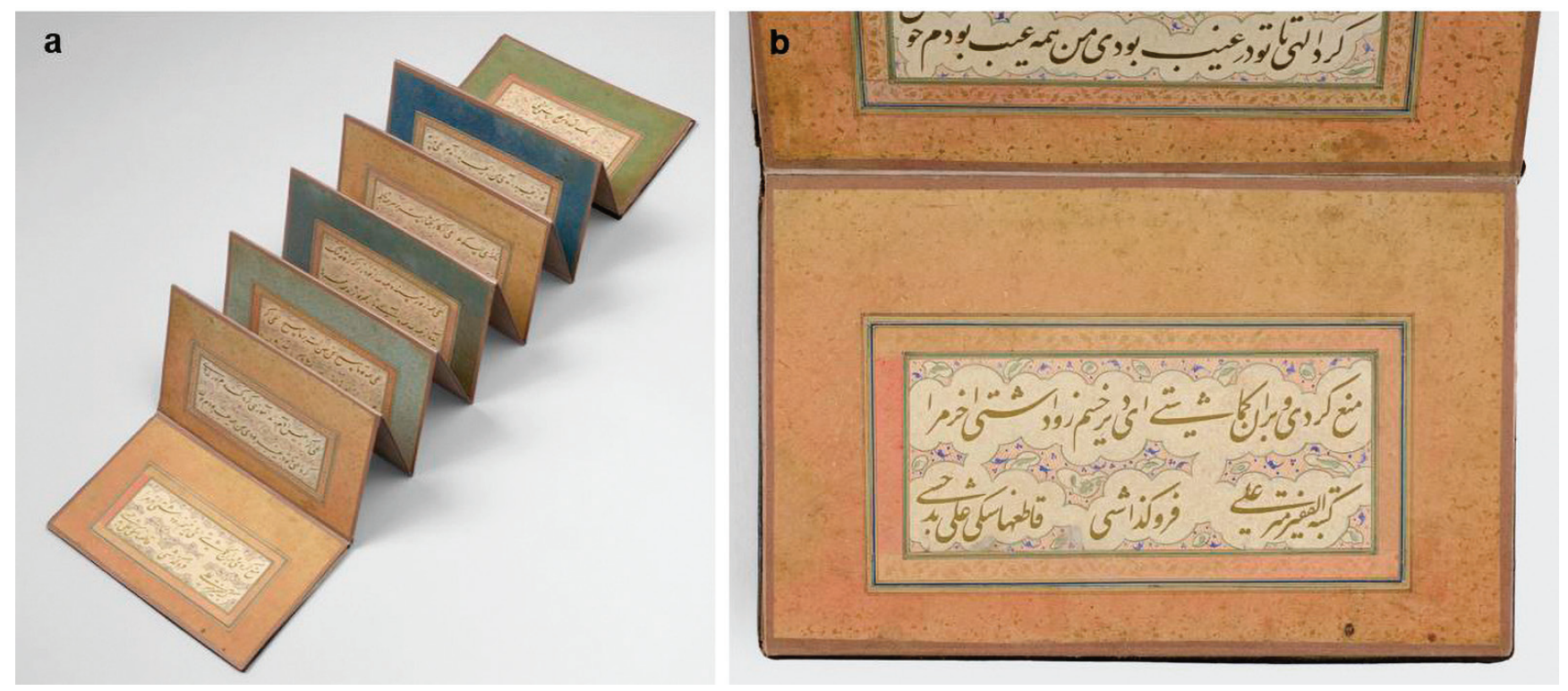

FIGURE 17

a. Concertina album of the Munājātnāma; b. names of Mir 'Alī and Sangī 'Alī Badakhshī, Musée du Louvre, MAO 2286

(C) MUSÉE DU LOUVRE, DIST. RMN-GP / HERVÉ LEWANDOWSKI a muraqqa sold in 2011 in Bonhams, one page from a Shāh Ismāill album at the Topkapı Palace Museum Library (mentioned above) and an album of calligraphy exercises at the Asian Civilisations Museum in Singapore, which will be discussed shortly. ${ }^{57}$

While admiring the various pages of the album, one experiences an overall impression of softness and fluidity. Both aspects reside in the way Sangī 'Alī Badahshī cut the letters: the edges of each letter being perfectly rounded and subtly integrated into the support. The flow of the calligraphy and the intervals between the words and the letters are rendered in a smooth and natural way. All in all, this contributes to the feeling of illusionism which is enhanced by the hues of the various framing papers, the exquisite illuminations and the soft shimmer of the golden letters.

Observation with a USB microscope combined with the raking light reveals the absence of any trace of ruling and indicates that the composition was executed without any guide (Fig. 18). ${ }^{58}$ Nevertheless, some letters are missing today, which allows us to gain insight into Sangī 'Alī's production process. The imprints left in the paper echo the exact shapes of the letters that are now missing. For example, the edges of the letter alef, in the first folios, are not sharp but smooth (Fig. 18a). This suggests that the outlines of the letters were not previously engraved in the background as they were in the Rijksmuseum folio, but that they were directly pasted and then hammered gently. Another theory is that the entire folio was put in a press to improve the adhesion of the letters to the ground. Even though the use of a press or hammer for this purpose is not mentioned in Zokā (2000), this does not mean that the tool, which was a common device in a kitābkhāna, was not used here. 

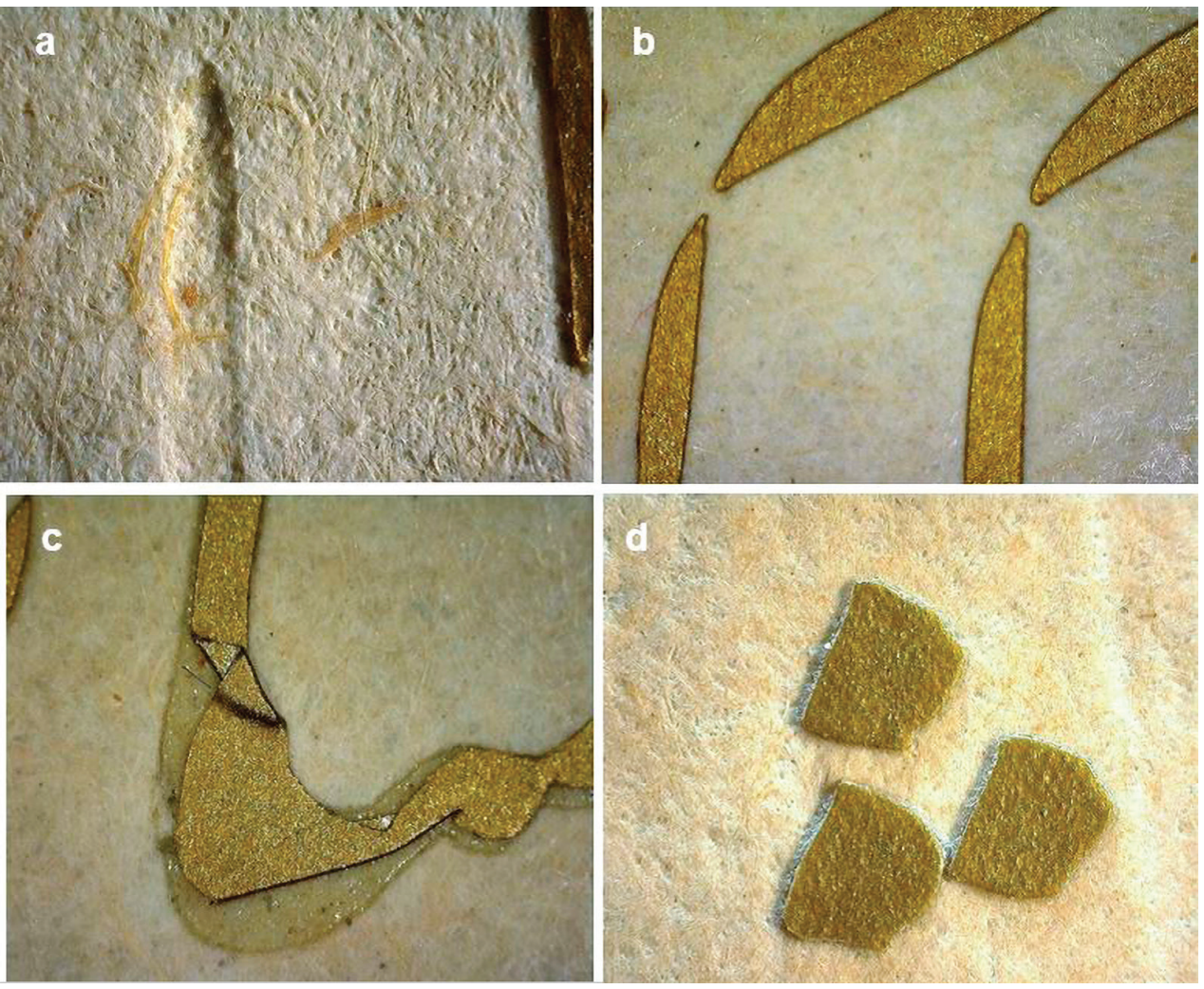

As for the letters themselves, they are perfectly cut and present no accidents or flaws. The letters $k \bar{a} f$ were cut into two parts: the upper elongated parts were cut separately and pasted only one millimetre from the rest of the letters (Fig. 18b). This was certainly done intentionally to enhance the areal impression that emerges from the composition. This aspect is also reinforced by the short alefs which vertically punctuate the lines and seem to float above the horizontal medians of the verses. The entire letters were cut from a gilded paper and therefore stand out clearly from the off-white ground. However, there are some flaws in the process indicated by the type of adhesive used and how it was applied. The accidents in some letters and the characteristic of the adhesive reveal that each letter was pasted individually and that the collage was still fresh when the folio was pressed. The yellowish and transparent texture could indicate that an animal or fish glue was used (Fig. 18c). Another interesting detail is that the dots used for the diacritics and vocalisations are not square as seen previously but have blunted contours as cut with free-hand (Fig. 18d). These contribute to the general impression of softness and roundness imbued with the calligraphic style of Mir 'Alī rendered by the skilful cuts of Sangī 'Alī Badahshī.

The Asian Civilisations Museum in Singapore holds an album by the two artists. ${ }^{59}$ The ten leaves present calligraphic exercises and, unlike the Louvre album, these are negative specimens for which a plain white paper was cut out, glued to coloured backgrounds in pink, blue and cream hues and framed with marbled and gold sprinkled papers. The last folio (Fig. 19), with the names of Mir 'Alī and Sangī 'Alī Badahshī, requires some reading effort because the now discoloured negative découpage does not stand out from the peachy background on which it was adhered. ${ }^{60}$
FIGURE 18

a. The missing alef; b. letters $k \bar{a} f$ constituted of two parts; c. gold particles embedded within the adhesive; d. dots cut with free-hand. Album of the Munājātnāma, Musée du Louvre, MAO 2286, micrographs $55 \mathrm{X}$ (C) A. COUVRAT DESVERGNES 
FIGURE 19

Last page of the album of calligraphy exercises with the names of Mir 'Alī and Sangī 'Alī Badahshī, inv. no. 1999.00799 (C) COLLECTION OF THE ASIAN CIVILISATIONS MUSEUM, SINGAPORE

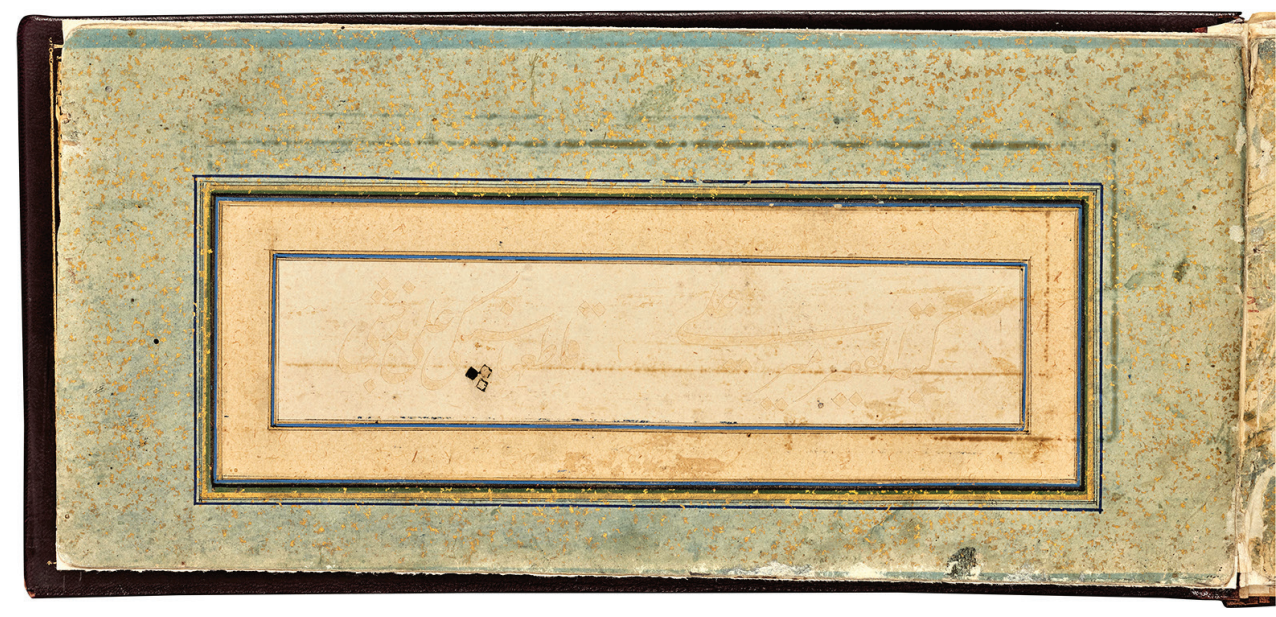

It is not certain that these specimens were originally intended to be preserved as works of art in their own right. The album is a recent arrangement with an illegible seal impression on the back. The binding in brown leather and a sort of lampas textile is a twentieth-century addition. The album was probably put together with offcuts from original exercise pages. In addition, the declensions of some letters are incomplete. For example, the exercise dedicated to the letter $\sin$ only shows a combination of $\sin$ and ye. The paper used for découpage is plain, barely sized and burnished, and shows signs of oxidation and foxing alongside usual traces of ageing and use such as stains and accretions. However, these specimens allow the exploration of Sangī 'Alī's negative cutting method. Throughout the letters, no flaws are noticeable along their outlines. Nevertheless, the somewhat uneven silhouettes of the dots give us the impression that these were cut free-hand and not with a ruler, which could have helped to achieve perfect angular squares. This particular aspect was also noted in the Louvre album. In the exercise folio dedicated to the mim, the contour of the letter is hesitant, as if the paper was slightly torn when the positive letter was taken off. Unlike the Louvre album, the $k \bar{a} f$ s were cut into one piece. However, the overall perception is steeped in fluidity and informality. All of these details may seem quite anecdotal and, again, more specimens should be investigated; however, these allow us to truly appreciate the performance and some of the processes involved in crafting such pieces.

\section{Further Discussion and Conclusion}

Different methods have been revealed through the three works studied above. To summarise, 'Abdallāh recut the letters after gluing and carried the dots with a pin. Dūst-Mohammad incised the background and inserted the cut letters into the hollow spaces in order to provide an optical effect of illusionism. Sangī 'Alī Badahshī performed a flawless composition in which no mark or correction is noticed. At this point, it is not known whether these technical characteristics are personal markers of the artists or experiences towards the goal of ultimate perfection. Other work still needs to be studied and compared to determine production patterns and personal practices. However, some questions remain open, in particular regarding the positioning and the pasting of the letters on the page. It is likely that the cutter used the negative matrix from which he extracted the cut letters, as a reference format, to position and glue the letters into the calligraphic panel. This hypothesis is corroborated by a copy of the Quran (Fig. 20) held by the Qatar National Library (QNL), which could be the key to understanding 
some crucial questions raised above. ${ }^{61}$ During the twentieth century, in Syria, there was a revival of découpage with the production of a Quran entirely made of muhaqqaq script. ${ }^{62}$ Each bifolium displays, to the right and to the left, the positive-negative complementary products, both resulting from the simultaneous cutting process and mirroring of one to the other. As for the QNL Quran, the positive cut located on the left folio shows the verses cut from a white page and pasted on the blue paper background, while the negative, on the right, represents the matrix that could have served as a guide to place the letters on the opposite page (Figs. 2ob and 2oc).
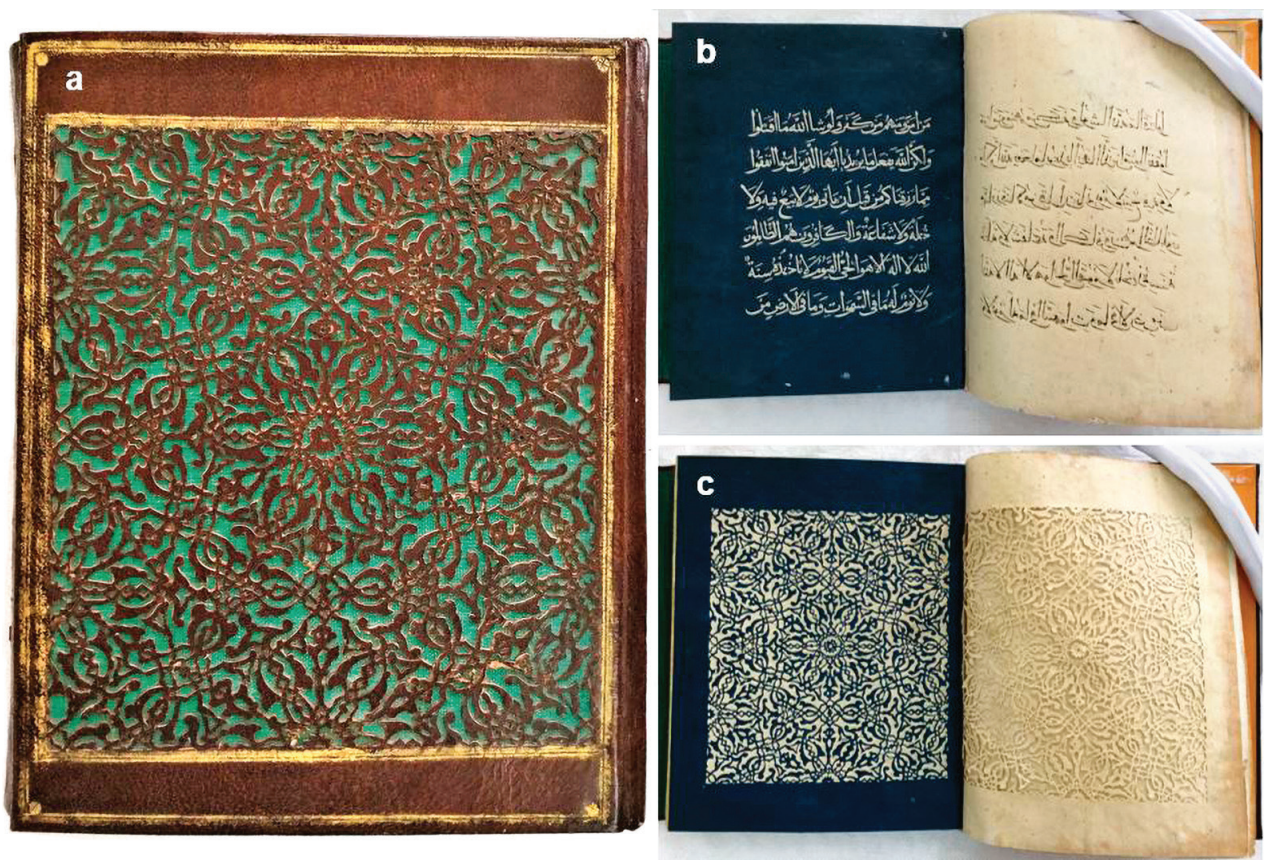

The negative and positive match perfectly while overlaying the two pages. We can therefore imagine that a similar process was carried out to compose a cut-out page during the sixteenth century: the negative cut-out was preserved and served as a guide for the positioning of the positive elements on another support. In addition, the QNL copy contains a double cut-out page which reproduces exactly the pattern found on the upper board of the binding: a leather filigree pattern made up of palmettes and arabesques in brown leather placed on a green fabric background. These characteristics could indicate that for this book, the artist was responsible for both the binding and the cut paper, and therefore that the same person cut the paper and the leather. This idea of a cutterbookbinder artist was brought up earlier when the transmission of the technique of cutting from binding to paper was introduced.

Regarding the process of pasting the letters on the support, two options are considered: either the entire background has been brushed with paste and the letters, previously cut, were affixed on it as long as the adhesive remained fresh and sticky, or the letters were pasted and affixed one by one. As we have seen, this last method was implemented by Sangī 'Alī Badahshī in the Louvre album. As for the Rijksmuseum folio, with careful observation under the stereomicroscope, no trace or residue of adhesive was found on the background paper and in the recessed areas. This might suggest that, for this specific case, the entire ground was coated with a light and diluted paste that has failed over time. As a result, letters are missing today. As for the folios of the divan of Sultan Husayn Bāyqarā, the entire surface appears coated and glossy. There are also a few small spots on the letters themselves which look like old and oxidised adhesive
FIGURE 20

Copy of the Quran: a. lower board of the binding with a brown leather filigree decoration laid on a green cloth; b. bifolio with positive and negative cut-out verses; $c$. the bifolio features the positive and negative découpage displaying a pattern of arabesques and palmettes. Ottoman Empire, probably Syria, HC. MS o267o, Qatar National Library, Heritage Library

(C) A. Couvrat DESVERGNes 
residue. On the BNF folio, the missing letters revealed no visible traces of underlying adhesive. Technically speaking, it is possible that a layer of paste was applied to the support, then the letters were affixed to this background, after which some letters were recut to correct their outline and the entire work was coated with a second application of paste and then burnished. This could explain the glossy surface and the perfect condition of these pieces and why today there are no letters or points missing in any of the folios dispersed in other institutions.

As onlookers, the question that comes to our mind is why such performances were made. Why produce such meticulous and daunting works, particularly if some cannot have been seen?

Some folios are difficult to read in normal light since the calligraphy and the background are ton sur ton. This is the case for the Doha folio Ms.81o and the Los Angeles folios M73-5-599 c., d. and f. and M.73.56.63 With specific lighting, it appears that the lines alternate subtle variations of white-based colours such as off-white, pale pink, pale blue and cream. However, these are barely readable today. Two possible reasons for this visual aspect are raised here: either it is accidental and results from the ageing of materials over time, or the visual effect was intentional. Regarding the first possibility, the artists working in the royal workshops were constantly motivated to achieve a high level of technical and aesthetic perfection that makes it hard to believe it was intentional. It is very likely that originally the letters were more visible but, over time, the paper used for the background and/or the letters discoloured, affecting the overall appearance of the folio and making the verses difficult to read today. As for the second possible reason, it could have been that the desired result was to create an illusionist effect and therefore an optical game that would have involved the physical interaction of the reader with the folio. The latter had to tilt the manuscript, bow his head, or change the direction or intensity of the light to uncover the mysterious words. This intention can be sustained later in the nineteenth century with a new step in the art of calligraphy in Qajar Iran, with the development of Hatt-i nāhoni, the so-called nail calligraphy in which the patterns or verses are not written but appear in relief by the action of a fingernail. On these, the words or the motifs revealed by the incidence of light on the paper and therefore the action of the viewer is necessary to fully perceive and appreciate the composition. ${ }^{64}$

This technical information having been clarified, the fundamental and probably more metaphysical question is: what were the motivations of the artists to constantly seek perfection and virtuosity? Of course, the constant quest for technical prowess was a recurring concern for artists working under high patronage. At the end of the fifteenth century, we also find calligraphy written in white ink on indigo blue paper. ${ }^{65}$ Usually in Iran, lead white was the preferred pigment for making white ink and paint. In order to prepare a good quality white ink, the lead carbonate particles must be ground extremely finely to produce a fluid medium material which would allow the ink to flow evenly from the qalam to the paper. ${ }^{66}$ The proportion of pigment and binder must also be adequate to avoid future mechanical degradation such as pulverulence, desiccation, cracking, losses or flaking. ${ }^{67}$ In order to write a delicate and valuable piece, the ink line must be seamless from the beginning of a word to its end and from the beginning to the end of the verse. White ink should also be opaque and have good covering properties to effectively cover the coloured paper underneath. Examples of white ink calligraphy show uneven application, markings of the pen movement across the page, when it was lifted at the end of its course to be reloaded with the medium and where it was laid on the surface to start its journey. Several pages also exhibit ink deterioration that have occurred over time such as loss and flaking as well as tarnishing. The latter is a chemical deterioration process, responsible for the darkening of the white pigment and for the alteration of the general aesthetics of the work. ${ }^{68}$ 
Therefore, it seems most likely that qat $t^{i} i$ was born from the artistic need to preserve a continuous flow of ink, to compensate for alterations and imperfections of the lead white and to ensure a flawless effect in the finished piece (Butler-Wheelhouse, 2017: 86). This aspect was certainly governed by the script itself, the nasta cli $q$, which requires the mastery and flexibility of the hand to achieve fluid and airy curves, lines and ligatures. One can easily imagine that $q a t^{t} i$ was much more labour-intensive and time-consuming and therefore more expensive than the usual inked writing. This is probably the reason why cutters were so few and why découpage calligraphy was commissioned only by wealthy patrons who could afford the sponsorship of a calligrapher, cutter, illuminator and other apprentices and craftsmen involved in the design of such books or albums. This is also certainly why, later in time, single cut-out specimens were made rather than entire volumes. It is hoped that additional specimens will be examined to further explore the various aspects of découpage raised in this study. These will enrich the body of knowledge of this particular art form and help to better understand the practice and the techniques involved.

\section{About the Author}

Amélie Couvrat Desvergnes is a paper and book trained conservator specialising in Islamic and Persian manuscripts and paintings on paper. Alongside her work in the field, she has carried out several research projects on the material aspects of these objects.

\section{Bibliography}

Adle, C. (1993). Les artistes nommés Dust-Mohammad au XVI e siècle. Studia Iranica 22, pp. 219-96. Akın-Kıvanç, E. (2007). Mustafa 'Alìs Epic Deeds of Artists: A Study on the Earliest Ottoman Text about the Calligraphers and Paintings of the Islamic World, MA Dissertation, The Ohio State University.

Blair, S. (2000). Color and Gold: The Decorated Papers Used in Manuscripts in Later Islamic Times. Muqarnas 17, pp. 24-36.

Bloom, J.M., and Blair, S.S., eds. (2009). The Grove Encyclopedia of Islamic Art and Architecture. Oxford: Oxford University Press.

Bosch, G., Carswell, J., and Petherbridge, G. (1981). Islamic Bindings and Bookmaking. London, Chicago: Oriental Institute, University of Chicago.

Butler-Wheelhouse, A. (2017). The Rhythm of the Pen and the Art of the Book: Islamic Calligraphy from the 13th to the 19th Century. London: Paul Holberton Publishing.

Çağman, F. (2014). Kat'i: Cut Paper Works and Artists in the Ottoman World. Istanbul: Aygaz Yayinlari.

Gulácsi, Z. (2005). Mediaeval Manichaean Book Art: A Codicological Study of Iranian and Turkic Illuminated Book Fragments from 8th-11th Century East Central Asia. Leiden: Brill.

Huart, C. (1908). Les calligraphes et les miniaturistes de l'Orient musulman. Paris: E. Lerous Editeur (repr. Osnabrück, 1972).

Michelsen, L., and Pelletreau, M., eds. (2013). Ferozkoh: Tradition and Continuity in Afghan Art. Doha: Bloomsbury Qatar Foundation Publishing.

Minorsky, V., trans. (1959). Calligraphers and Painters: A Treatise by Qādī Hamad (circa A.H. 1015/A.D. 1606). Washington: Freer Gallery of Art.

Ohta, A. (2004). Filigree Bindings of the Mamluk Period. Muqarnas 21, pp. 267-76.

Ohta, A. (2012). Covering the Book: Bindings of the Mamluk Period, 1250-1516 CE, PhD Dissertation, Department of the History of Art and Archaeology, School of Arts, SoAs, University of London. 
Prisse d'Avennes, E. (1877). L’Art Arabe: les monuments du Kaire: depuis le VII siècle jusqu'à la fin $d u X V I I I^{e}$. Paris: J. Savoy et Cie Editeurs.

Rogers, J.M. (1999). Ornament Prints, Patterns and Designs East and West. In: C.S.F. Burnett and A. Contadini, eds., Islam and the Italian Renaissance, Warburg Institute Colloquia 5, London: The Warburg Institute, pp. 133-65.

Roxburgh, D. (2013). The Persian Album, 1400-16oo: From Dispersal to Collection. New Haven: Yale University Press.

Roxburgh, D., and McWilliams, M. (2007). Traces of the Calligrapher: Islamic Calligraphy in Practice, c. 1600-1900. Houston: Museum of Fine Arts.

Schmitz, B. (1993). Cut Paper. In: Encyclopaedia Iranica, https://bit.ly/3vOc4aE.

Seipel,W., ed.(1998).Schätze der Kalifen.Islamische KunstzurFatimidenzeitEine Sonderausstellung des Kunsthistorischen Museums im Künstlerhaus. Exhibition Catalogue, 16 November 1998 to 21 February 1999. Milan: Skira.

Soucek, P. (1988). Bābā Jān Koorāsānī. In: Encylopaedia Iranica, https://iranicaonline.org/articles/ baba-jan-korasani.

Tākestānī, A.M. (1993). Rāhnamāa-yi Naqū̌̌š va Ketāb-Ārāyē dar Irān [Painting and Book Design Guide in Iran]. Tehran: Kachakter.

Thackston, W.M. (200o). Album Prefaces and Other Documents on the History of Calligraphers and Painters. Leiden: Brill.

Warner, J. (1978). Chinese Papercuts. Hong Kong: John Warner Publications.

Yusen, Y. (2018). Representing Ming China in Fifteenth-Century Persianate Paintings. Ming Studies 78, pp. 57-73.

Zhang, D. (1989). The Art of Chinese Papercuts. Beijing: Foreign Languages Press.

Zokā, Y. (2000). Honār-i kāgazazborī dar Irān [The Art of Cut Paper in Iran]. Tehran: Farzān Publications.

\section{Notes}

1 The author wishes to thank Charlotte Maury, curator at the Département des Arts de l'Islam (Musée du Louvre); Mounia Chekhab Abudaya, curator of North Africa and Iberia at MIA; Francis Richard (CNRS); Yves Porter (Université Aix-Marseille, France); Jake Benson, research associate (Persian manuscripts) at the John Rylands Library, Manchester; Rachael Smith, paper conservator at the Royal Collection Trust Windsor Palace; Stéphane Ipert, head of conservation at the Qatar National Library; Forough Sajadi, researcher at Institute for Area Studies, Leiden University; and Nil Baydar, director of the Kitap Şifahanesi ve Arşiv Dairesi Başkanlığı.

2 The acquisition number of the recto is RP-T-1993-462 (R) and of the verso RP-T-1993-462 (V).

3 In the last part of this paper, significant but later specimens (dated twentieth century), featuring both types united in the same book, are presented. A page from the Morgan Library signed Mir 'Alī presents negative and positive verses on the same support but these are not the results of the same cutting process; see www.themorgan.org/blog/materials-and-decorative-techniques-read-album-leaves. Chapter 4 is entitled "On Painters, Gilders, Masters of Gold Sprinkling and 'découpé' Work, Dyers of Paper, and on Other Cognate Matters."

$5 \quad$ See Schmitz (1993).

6 Victoria \& Albert Museum, steIn.483 (on loan from the Government of India and the Archaeological Survey of India), http://collections.vam.ac.uk/item/085719/the-stein-collection-paper-flowers -unknown/, and British Museum, MAS.913.a-d and 1919,0101,0.230.1 and 1919,0101,0.230.2, www .britishmuseum.org/collection/search?keyword=Turfan\&object=papercut\&view=grid\&sort=obj ect_name_asc\&page $=1$.

7 Dimensions: $416 \times 302 \mathrm{~mm}$.

8 See online catalogue entry: https://gallica.bnf.fr/ark:/12148/btvib830o1ork.r=Pelliot\%2ochinois\%20 $4518 \% \mathrm{EF} \% \mathrm{BC} \% 8838$ ?rk=21459;2.

9 Bookbindings MIK III 6267, 6268 and 7048 in the Museum of Indian Art, Berlin.

10 MIK III 6268, SMPK, Museum of Indian Art, Berlin. Dimensions: $90 \times 110 \mathrm{~mm}$. An image and the virtual reconstruction of the binding MIK III 6268 are reproduced in Gulácsi (2005: 84) (the blackand-white reproduction does not allow the viewing of the gilded paper background). 
11 Dimensions: $75 \times 65 \mathrm{~mm}$.

12 BNF, Arabe 5845, https://gallica.bnf.fr/ark:/12148/btvıb841923Oz.r=Arabe\%205845.?rk=21459;2.

13 For more details about filigree used in Mamluk bindings, see Ohta (2012: 26o-79).

14 P. Vinob. Ach 25.636, P. Vinob. Ach 25.638 and P. Vinob. Ach 25.639.

15 P. Vinob. Ach 25.636. Dimensions: $207 \times 44 \mathrm{~mm}$.

16 Acc. no. 1978.546.42, www.metmuseum.org/art/collection/search/4529o3, and 1978.546.43, www. metmuseum.org/art/collection/search/452904.

17 Acc. no. 1978.546.45. Dimensions: $286 \times 203 \mathrm{~mm}$.

18 Plates CLXXV and CLXXVI. See New York Public Library Digital Collection: https://digitalcollections. nypl.org/items/51od47d9-67f8-a3d9-eo4o-eooa18o64a99 and https://digitalcollections.nypl.org/ items $/ 510 d 47$ d9-67fa-a3d9-eo4o-eooa18o64a99.

19 Doublures of the Shāhnāma of Firdowsī, dated 899/1494 (TIEM, 1978).

20 British Library Add.7759 and Add.16561. Copy of the Mahzan al-Asrār, Spencer Persian 41, New York Public Library.

21 Informal communication with Jake Benson and Yusen Yu.

22 She describes the full-page compositions featuring magnificent arabesques cut from white papers laid on deep blue or salmon pink grounds and finely crafted horses as the paper pendants of leatherembossed bookbinding, carpet or tiles designs, book illumination and illustrations. Elegant trees inhabited by graceful birds are inspired by the symbolic motif of the sacred tree particularly vivid in the Qaraqoyunlu and Turk popular cultures. In addition, intriguing cut-out specimens representing mythical beasts with seven heads recall, according to the author, the appliqué motifs found in felt and leather goods from the third- to second-century вс Pazyryk burial mounds, motifs which were introduced by the Turks via ninth- to tenth-century Seljuk ceramics and metalworks. The same album comprises also many cut-out calligraphies in the form of black, cream golden letters cut in thuluth, ta'liq, riq'a and muhaqqaq scripts and laid onto pink, cream and blue coloured paper grounds.

23 The text is a compilation of aphorisms, or One Hundred Sayings, attributed to the fourth caliph of Islam, 'Alī b. Abī Tālib in 6o1/1204.

24 Roxburgh (2013) qualifies the album as "one of the most astonishing examples of decoupage."

25 Fol. 11r., 12v., 179r., 18or. and 19or.

26 The entry "papercut" mentions that the origins of "collage and decoupage" are in Egypt and Syria and that the technique reached Iraq and Iran during the rule of the Timurid dynasty.

27 See the bookbinding of the well-known copy of the Ketāb-i Sitta by Farīd al-Dīn 'Atțār produced for Shāhruhr in 1438, Topkapı Palace Museum Library (A.3059). The intricate patterns of red leather cut displays within trees and foliage animal figures of birds, fish, lions and other fantastic creatures on a lapis blue ground.

28 Warner (1978) also states that, for Chinese papercut, the technique requires "no elaborate methods or daunting arrays of tools." The set of tools comprises extremely sharp blades held between slivers of bamboo, a sharpening stone, sharp pointed scissors, a pair of metal tweezers, some pins, a bag of flour and a broad flat knife.

29 Topkapı Palace Museum Library (C.Y.438). The author was unable to obtain an image of the tool for this article, which is why a drawing is offered here but thanks to Nil Baydar for sending a photograph of the tool on which the diagram is based.

$30 \quad$ For Chinese papercut, Warner describes the use of a sort of wooden tray with a rim filled up with melted animal fat thickened with finely ground charcoal powder. Then the box was gently warmed up and the melted ingredients were pressed and levelled to form an even surface. Zhang adds that the latter was eventually sprayed with a flour of water chestnut, sweet potato or talcum in order to prevent the paper sticking to the substance or moving during the cutting process. Moreover, the stack of papers to be cut was secured onto the tray with some pins in the four corners. This device constituted a semi-soft support on which the artisan could cut safely his design without damaging either the paper or his tools. The tray could be gently warmed up again to melt the content, level it up with the flat broad knife and allow further use. Such a material is not mentioned by Zokā (200o), who only cites the use of the pištahtah.

31 See an iron awl (acq. no. 404-1885) from the Victoria and Albert Museum dated nineteenth century in Iran, https://collections.vam.ac.uk/item/O1331191/awl-bookbinding-tool/.

32 The dimensions of Ms.8O9.MIAQ and Ms.8O1.MIAQ are $238 \times 153 \mathrm{~mm}$ and $237 \times 155 \mathrm{~mm}$, respectively. The dimensions of RP-T-1993-462 are $164 \times 95 \mathrm{~mm}$.

33 The rest of the folios are today in LACMA in Los Angeles (M.73.56; M.73.5.599, a-b, c-d and e-f), Brooklyn Museum (1-87-154.152), Aga Khan Museum in Toronto (AKM227), the Freer \& Sackler Galleries, Smithsonian Institution (F1929.66-67), the Cincinnati Art Museum (2016.372) and the Library of Congress in Washington (F1929.66-67). Three split pages are mounted in an album for Sultan Murad III now held in the Österreichische National Bibliothek (Codex Mixtus 313, fol. 23a and $30 a, 32 b)$, and another page was sold in 2018 by Bonhams, New York, April 24, lot 325 . 
According to Schmitz (1993), the folio with the name of 'Abdallāh is in Istanbul whereas Sultan 'Alī Mashhadī's name appears on another page held in the Āydīn Āḡdāslū collection in Iran. The information is not confirmed by Çağman (2014).

Unknown shelf-mark; the letters of Sultan 'Alī Mashhadī and Šayh 'Abdallāh were cut out off a yellow paper and laid onto an indigo blue ground surrounded by a series of highly illuminated coloured borders, https://bit.ly/2SXEtho.

The panel at the bottom left of the page displays both names of Sultan 'Alī Mashhadī and Šayh 'Abdallāh written in yellow, pink and white letters on a deep blue background, Topkapı Palace Museum Library (H.2154, Fol. 43r., 43v., 5or. and 52r.).

A PhD thesis by Sevgi Kutluay on the corpus of the dīvān is currently under completion at Hacettepe University in Ankara.

This particular aspect was informally discussed with Jake Benson and will be addressed alongside other questions related to folio and bifolio construction, additional margins and insets in his forthcoming PhD thesis, "The Advent of Abrī: The First Wave of Paper Marbling during the Long 16th Century," Leiden University.

For an example, see www.metmuseum.org/art/collection/search/452420?searchField=All\&amp;sor $\mathrm{tBy}=$ Relevance\&amp;ft=ruling+board\&amp;offset=o\&amp;rpp=2o\&amp;pos=2.

The ruling is entirely or partially visible on the digital images of AKM227, Brooklyn Museum 45.4.3, Freer Sackler Fig29.67, LACMA M.73.5.599 b, c, d, e, f and M73.56.

Dimensions: $164 \mathrm{~mm} \times 95 \mathrm{~mm}$.

The other folios from this manuscript have not been identified in any collection so far.

See Soucek (1988).

See notice in http://wikifeqh.ir/حافظ_اباجان.

Adle (1993) provides a complete study on the different names and their respective works.

Colophon in a copy of the Munäjātnāma (private collection) mentioned by Adle (1993): PL.Ix, Fig.6.

The folio 5 or. from the Bahrām Mīrzā album, Topkapı Palace Museum Library (H.2154), features both names of the father and the son, Ibn Šayh 'Abdallāh and Šayh 'Abdallāh (Çağman, 2014: 88-9).

He was a painter and a cutter and performed a cut-out piece from a calligraphy by Shāh Mahmūd in the Bahrām Mīrzā album, Topkapı Palace Museum Library (H.2154, Fol. 125r.).

Page cut by Dūst-Moḥammad from Mir 'Alī's calligraphy in a private collection, http://cdn.simplesite.com/i/86/86/2856971069275849o2/i28569711438658o966._szw128oh128o_.jpg.

Associated on the same folio to a calligraphy signed 'Ali from the Amīr Byg album preserved at the Topkapı Palace Museum Library (H.2161, Fol. 66r.).

The micrographs were taken with the digital microscope HIROX-RH 2000, a $3 \mathrm{D}$ image-rendering system, with which the images are captured at multiple planes with an automatic Z-axis drive for precise image plane intervals and height information.

The folio is a double-sided page, the recto ( $\mathrm{RCIN} 100547 \mathrm{R})$ showing a prince reciting poetry to his attendants in a garden and the verso (RCIN $100547 \mathrm{~V}$ ) displaying the cut-out calligraphy specimen. Thanks go to Jake Benson for the identification of the work. Dimensions: $371 \times 239 \mathrm{~mm}$, www.rct.uk/ collection/1005047/a-prince-recites-poetry-to-attendants-in-a-garden-by-lal-calligraphy-attributed.

The piece is signed فقير المذنب على or "the poor sinner 'Alī."

At top, bottom and left, the verses by Moḥammad Ḥusaynare from Abū Sa'īd Abū al-Hुayr are calligraphed onto a background of marbled paper with blue and white swirling motives. The outer borders of cream paper are decorated with sanz motives and vegetal scrolling painted in gold.

The author is indebted to Rachael Smith, paper conservator at the Royal Collection Trust, for providing the micrographs.

Topkapı Palace Museum Library (H.2138). The album's creation began in 1568-9 in Mashhad and was completed in $1578-9$.

The Morgan Library, Ms M.458, folio 12v.

Acc. no. 67.266.7.6v, www.metmuseum.org/art/collection/search/451975, Bonhams, Islamic and Indian Art, sale 18950, October 4, 2011, lot 42.

The micrographs were taken with the Dinolite ${ }^{\circ}$ AM4113T-FVW (R4).

Acq. no. 1999-00799. Dimensions: $112 \times 230 \mathrm{~mm}$.

The folios read كَّه الفقير مير على قاطعها سنكى على بدخشى or "calligraphed by the poor Mir 'Alī and cut by Sangī 'Alī Badahshī.”

Copy of the Quran, from Syria (?), twentieth century, HC. MS 02670, Qatar National Library, Heritage Library. The calligraphy is signed by Arghun.

Chritie's sale 5100, London, October 16, 2007, lot 419, and Christie's sale 9547, London, October 11, 2013, lot 795 .

See https://collections.lacma.org/node/240330 and https://collections.lacma.org/node/2261916. 
64 See the video on an artist at work in the recent online publication, "Fingernail Art (I): Threedimensional Calligraphy and Drawing in the 19th-Century," https://digitalorientalist.com/2020/12/ 11/fingernail-art-three-dimensional-calligraphy-and-drawing-in-19th-century/.

65 See a page with white ink on a blue paper ground, dated 1470, from the Aga Khan Museum in Toronto, AKM257, https://agakhanmuseum.org/collection/artifact/blue-dyed-folio-from-a-manuscript-of -poetry-akm257.

66 Lead white pigment $2 \mathrm{PbCO}_{3} \cdot \mathrm{Pb}(\mathrm{OH})^{2}$ is manufactured from lead scraps exposed in a closed environment to acidic vapour in contact with moisture and carbon dioxide emitted by the fermentation of horse manure, waste grape skins and tan bark. The resulting product, the basic lead carbonate, is then treated to produce the white pigment.

67 A composition folio of calligraphy specimens from the 1544-5 album made for Prince Bahrām Mīrzā (1517-49) displays white ink losses, flaking and tarnishing, Boston Museum of Fine Arts, 14.545 (verso), https://collections.mfa.org/objects/13834/prince-and-lady-under-flowering-branch?ctx=5c 84b822-26e6-433d-bfa5-da42a582dcee\&idx=o.

68 Tarnishing or darkening is a natural ageing process of the lead white which, under the action of sulfur and pollutants, becomes a lead sulfide and turns black. For an example of extensive areas of white lead flaking, see a folio signed by Kamāl al-Din Ikhtiyār, c. 1540-50, Freer Gallery Smithsonian, F.1929.65, https://asia.si.edu/object/Fr1929.65/. 